Georgia State University

ScholarWorks @ Georgia State University

8-8-2017

\title{
Comagmatic Evolution of the Boulder and Pioneer Batholiths of Southwest Montana
}

John Bankhead

Follow this and additional works at: https://scholarworks.gsu.edu/geosciences_theses

\section{Recommended Citation}

Bankhead, John, "Comagmatic Evolution of the Boulder and Pioneer Batholiths of Southwest Montana." Thesis, Georgia State University, 2017. doi: https://doi.org/10.57709/10448093

This Thesis is brought to you for free and open access by the Department of Geosciences at ScholarWorks @ Georgia State University. It has been accepted for inclusion in Geosciences Theses by an authorized administrator of ScholarWorks @ Georgia State University. For more information, please contact scholarworks@gsu.edu. 


\title{
COMAGMATIC EVOLUTION OF THE BOULDER AND PIONEER BATHOLITHS OF \\ SOUTHWEST MONTANA
}

by

JOHN BANKHEAD JR.

Under the Direction of Paulo Hidalgo, $\mathrm{PhD}$

\begin{abstract}
The tectonic region that encompasses Southwestern Montana is a petrologically complex area containing several batholiths and thrust faults, underlined by Precambrian basement rock and capped by sedimentary rocks. Intrusive volcanism of Southwest Montana best represented by the Pioneer and Boulder batholiths is a product of the eastward subduction of the Farallon Plate underneath the North American Plate during the Mesozoic time. Geochemical modeling made evident that the Pioneer and Boulder batholiths have a comagmatic relationship. This conclusion is derived from variation, spider and REE diagrams along with petrographic and geochemical models. The intrusion of these batholiths is likely related to the emplacement of a detached portion of the Idaho batholith known as the Sapphire block. Future models that are outside of the scope of this research must consider the evidence proposed in this document to produce an overarching model
\end{abstract}


for the intrusion of the Pioneer and Boulder batholiths in the incredibly dynamic tectonic setting of the Mesozoic.

INDEX WORDS: Pioneer batholith, Boulder batholith, SW Montana 


\section{COMAGMATIC EVOLUTION OF THE BOULDER AND PIONEER BATHOLITHS OF \\ SOUTHWEST MONTANA}

by

JOHN BANKHEAD JR.

A Thesis Submitted in Partial Fulfillment of the Requirements for the Degree of Master of Science

in the College of Arts and Sciences

Georgia State University

2017 
Copyright by

John G. R. Bankhead Jr. 2017 


\section{COMAGMATIC EVOLUTION OF THE BOULDER AND PIONEER BATHOLITHS OF SOUTHWESTERN MONTANA}

by

JOHN BANKHEAD JR.

Committee Chair: Paulo Hidalgo

Committee: Hassan A. Babaie

Brian K. Meyer

Electronic Version Approved:

Office of Graduate Studies

College of Arts and Sciences

Georgia State University

August 2017 


\section{DEDICATION}

I would like to dedicate this to my mother and father. I thank you for the support you have given throughout my life as well as the tools and opportunity you provided to succeed in this world. 


\section{ACKNOWLEDGEMENTS}

I would like to acknowledge Dr. Paulo Hidalgo for the guidance, support and encouragement he provided throughout this process. I could not have done it without him. I would also like to thank my committee, Dr. Brian Meyer and Dr. Hassan Babaie for their input and guidance as well. I would also like to thank Mark Poole, Russ Kirn and Jude Waguespack for the work collecting the samples used in this project. 


\section{TABLE OF CONTENTS}

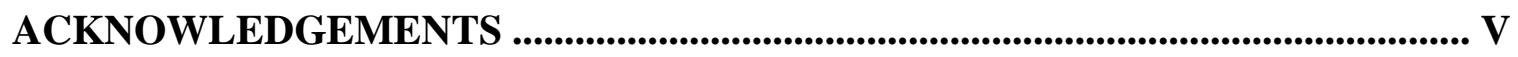

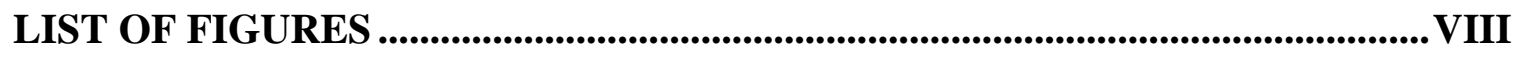

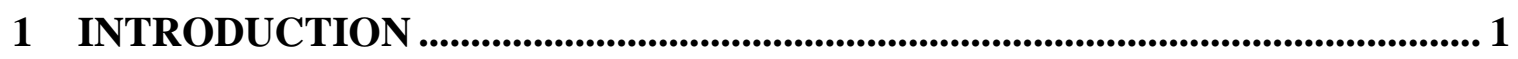

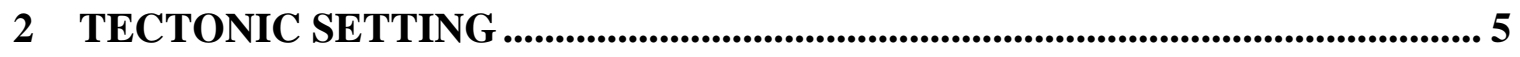

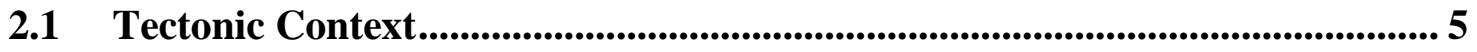

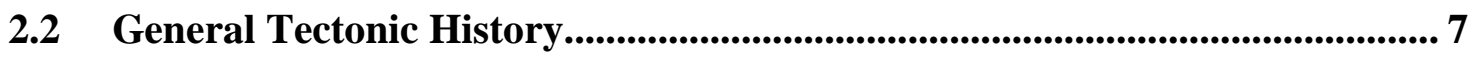

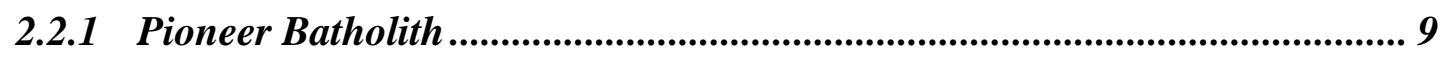

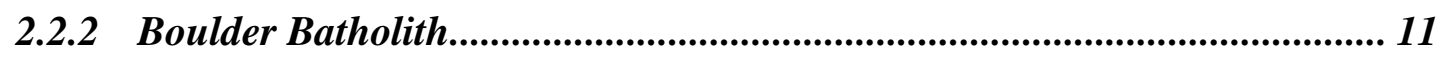

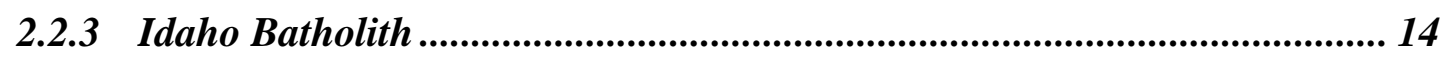

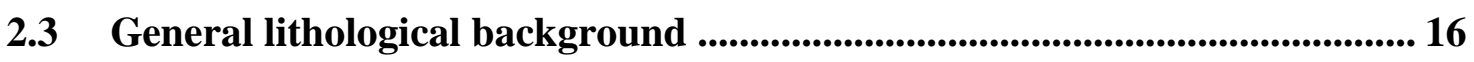

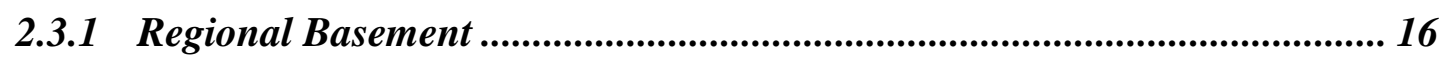

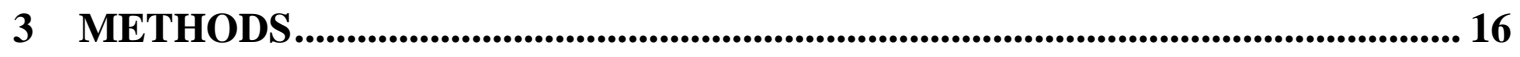

3.1 Pioneer and Boulder Batholith sample collection ....................................... 16

3.2 Bulk geochemical analysis ............................................................................... 16

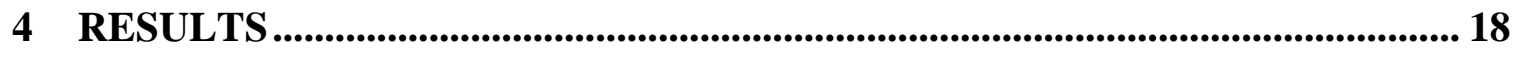

4.1 Geochemistry of Pioneer Mountain Batholith ............................................ 18

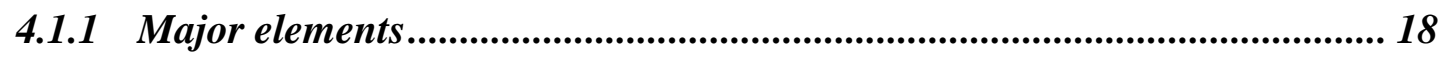

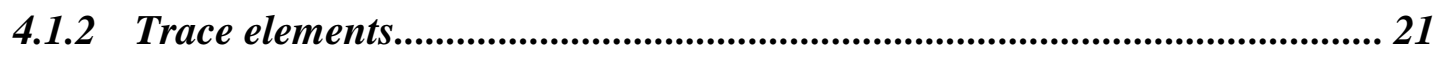

4.2 Petrographic analyses of Pioneer batholith end members ......................... 25 


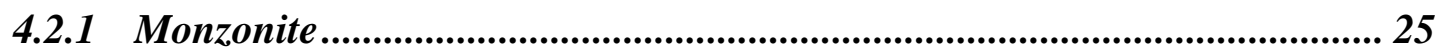

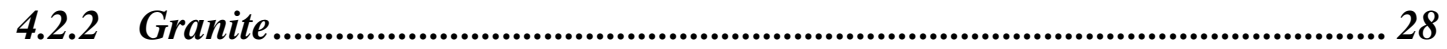

4.2.3 Relationship between the Monzonite and Granite......................................... 28

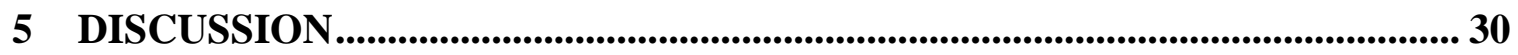

5.1 Chemical and mineralogical variation of SW Montana batholiths ............... 30

6 CONCLUSIONS............................................................................................................... 38

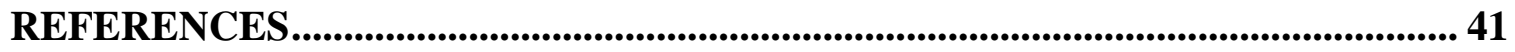

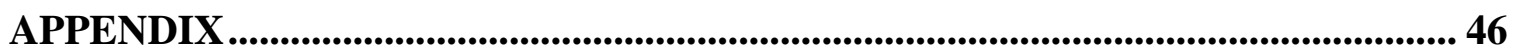




\section{LIST OF FIGURES}

Figure 1 Tectonic map of western Montana. Location of the Idaho, Pioneer, and Boulder batholiths from Foster et al., 2012. Thrust sheets west of the Boulder batholith are part of the Sapphire Block that detached along the Bitteroot detachment zone.......................... 3

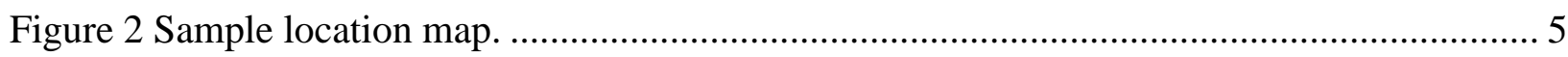

Figure 3 TAS diagram from Le Bas et al., (1986) showing Pioneer batholith sample plots. Most samples plot within the basalt and dacite fields with one sample plotting in the basalticandesite field and one sample plotting the rhyolite field. 19

Figure 4 Bulk rock geochemistry. Harker variation diagrams plotting major oxides vs. $\mathrm{SiO}_{2}$. Noticeable decreases in $\mathrm{CaO}$ correlate to amphibole fractionation along with increasing $\mathrm{Al}_{2} \mathrm{O}_{3}$ ?then decrease with increasing silica content. 20

Figure 5 Trace Element Harker diagrams. Pioneer batholith trace element samples plotted vs. $\mathrm{SiO}_{2}$. Sr decreases with increasing $\mathrm{SiO}_{2}$ content, evidence for plagioclase fractionation. $\mathrm{Ba}$ and $\mathrm{Rb}$ increase are indication of crustal contamination. All trace elements are presented in ppm.

Figure 6 REE \& Spider diagrams. Blue lines represent silicic samples and yellow lines represent mafic samples for the Pioneer batholith. Eu peaks in mafic samples and troughs in silicic sample indicate plagioclase accumulation and fractionation, respectively. The "spoonlike" shape of the REE diagram is evidence for amphibole fractionation.

Figure 7. Thin section of Pioneer batholith sample 002. Noticeable plagioclase accumulate texture with interstitial quartz grains. Thin section under cross-polarized light 26

Figure 8 Thin section of Pioneer batholith sample 001. Amphibole pictured with intergrowths of plagioclase. Thin section is under cross-polarized light. 27 
Figure 9 Thin section of Pioneer batholith sample 001. Large grains of plagioclase with albite twinning and amphibole are present with some interstitial quartz grains. Thin section is under cross-polarized light.

Figure 10. TAS diagram, all samples. Blue diamonds are Pioneer batholith samples; red triangles are Boulder batholith samples. Yellow blob represents Idaho batholith sample field from Clarke, 1990 and red blob represents the Boulder batholith sample field from du Bray et

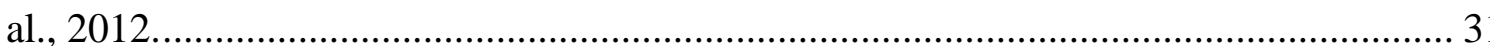

Figure 11. Harker variation diagrams. Blue diamonds represent the Pioneer batholith and orange squares represent the Boulder batholith samples. Boulder batholith samples follow a smooth trend in line with the Pioneer samples and bridge the gap between the low and high silica members.

Figure 12. REE and Spider diagrams. Black lines represent Pioneer batholith samples. Shaded pink fields represent Boulder batholith samples, and shaded green areas represent Idaho batholith samples from Clarke 1990.

Figure $13 \mathrm{Dy} / \mathrm{YB}$ vs $\mathrm{SiO}_{2}$. The decrease of the $\mathrm{Dy} / \mathrm{Yb}$ ratio as $\mathrm{SiO}_{2}$ decreases is indicative of amphibole fractionation. 36

Figure $14 \mathrm{Ba} / \mathrm{Sr}$ vs $\mathrm{SiO} 2$ showing fractionation of plagioclase. $\mathrm{Ba} / \mathrm{Sr}$ ratios increase as $\mathrm{SiO}_{2}$ content increases showing plagioclase and not potassium feldspar was the dominant fractionating phase.

Figure $15 \mathrm{CaO} / \mathrm{Al}_{2} \mathrm{O}_{3}$ vs. $\mathrm{MgO} /\left(\mathrm{MgO}+\mathrm{Fe}_{2} \mathrm{O}_{3}\right)$. The $\mathrm{MgO} \#$ represents the more mafic melts as $\mathrm{SiO}_{2}$ varies little in these liquids, the $\mathrm{CaO} / \mathrm{Al}_{2} \mathrm{O}_{3}$ vs. $\mathrm{SiO}_{2}$ represents the removal of plagioclase across the entire suite of PM samples 


\section{INTRODUCTION}

The intrusive volcanism of Southwest Montana best represented by the Pioneer and Boulder batholiths, is a product of the eastward subduction of the Farallon Plate underneath the North American Plate during the Mesozoic. The emplacement of these batholiths is related to a detached portion of the Idaho batholith known as the Sapphire Block. In the following pages of this document, I will present evidence that is consistent with the Pioneer and Boulder batholiths sharing a magmatic source that was affected by crystal fractionation processes.

In continental arc settings, processes such as partial melting of continental crust (White and Chappell, 1983; Vielzeuf and Holloway, 1988), assimilation of continental crust and fractionation are quite common (DePaolo, 1981; Hildreth and Moorbath, 1988).

These processes make subduction zones environments where the exchange of mantle and crustal material is possible. This exchange plays a central role in the evolution of the continental crust and the Earth's mantle. The mantle and crustal components of this exchange are the subducting oceanic crust (and overlying sediment) along with the peridotites within the mantle wedge. This process initiates when fluids from the dewatering subducted sediments and hydrothermally metamorphosed crustal materials are fluxed into mantle rocks triggering melting (Davies and Stevenson 1992; Forneris and Holloway 2003; Grove, et al. 2002; Schmidt and Poli 1998; Tatsumi and Eggins 1995; Ulmer 2001). Mantle decompression may aid this process from subduction-induced corner flow in the mantle wedge (Elkins-Tanton, et al. 2001; Hasegawa and Nakajima 2004; Sisson and Bronto 1998). The resulting primary magmas are subsequently transferred into the overlying crust where AFC (Assimilation, Fractional Crystallization) (DePaolo 1981) and mixing processes are responsible for the chemical variety observed on continental arcs. 
Magmatism in Southwestern Montana and Idaho started 100 Ma and stopped at around 40 Ma. This determination is best represented by a few reliable ages that have been calculated for the Idaho batholith (Armstrong, Taubeneck, \& Hales, 1977; Mcdowell \& Kulp, 1969). The Idaho batholith has a complex structure, composition, and history and is believed to have been emplaced from 100 to $44 \mathrm{Ma}$ (Mueller \& Shuster, 1995). Ages calculated for the Pioneer and Boulder batholiths fall within this period and are associated with magmatism during the Late Cretaceous time, both of these batholiths are thought to have emplaced between 78 and $65 \mathrm{Ma}$ (du Bray et al., 2012; Lund et al., 2002).

The batholiths of Southwestern Montana have been analyzed in many studies detailing duration of magmatism, petrology of constituent plutons, and their relations to nearby volcanic rocks (Bennett, 1980; du Bray, Aleinikoff, \& Lund, 2012; Foster, Mueller, Heatherington, Gifford, \& Kalakay, 2012; Hamilton \& Myers, 1974; Hammarstrom, 1982; Hyndman, Talbot, \& Chase, 1975; Mueller \& Shuster, 1995). Even with the plethora of studies, many questions remain related to the emplacement processes and the development and growth of these batholiths and the magmatic relationship between these plutons.

Correlation of the different batholiths in the area is still a controversial topic. The Boulder and the Pioneer batholiths seem to be over $25 \mathrm{~km}$ east of where geologists believe they should have been emplaced. The emplacement of these intrusive bodies appears to be directly related to the detachment of a large crustal block from the rising Idaho batholith infrastructure. This 10- to 15-km thick block is known as the Sapphire block. It seems no coincidence that the Boulder batholith and related plutons are the only large Cretaceous calc-alkaline plutons to occur within the overthrust belt and that they are closely related spatially to the Sapphire block (Hyndman et al., 1975). 
The central hypothesis of my project is that the Pioneer and Boulder batholiths are derived from the same magma source, but their chemical composition reflects different evolutionary stages in the liquid line of descent. I will show that the chemistry of the Boulder batholiths could be reproduced by fractionation of principal mineral species from a single parental basalt found in the Pioneer batholith sample suite.

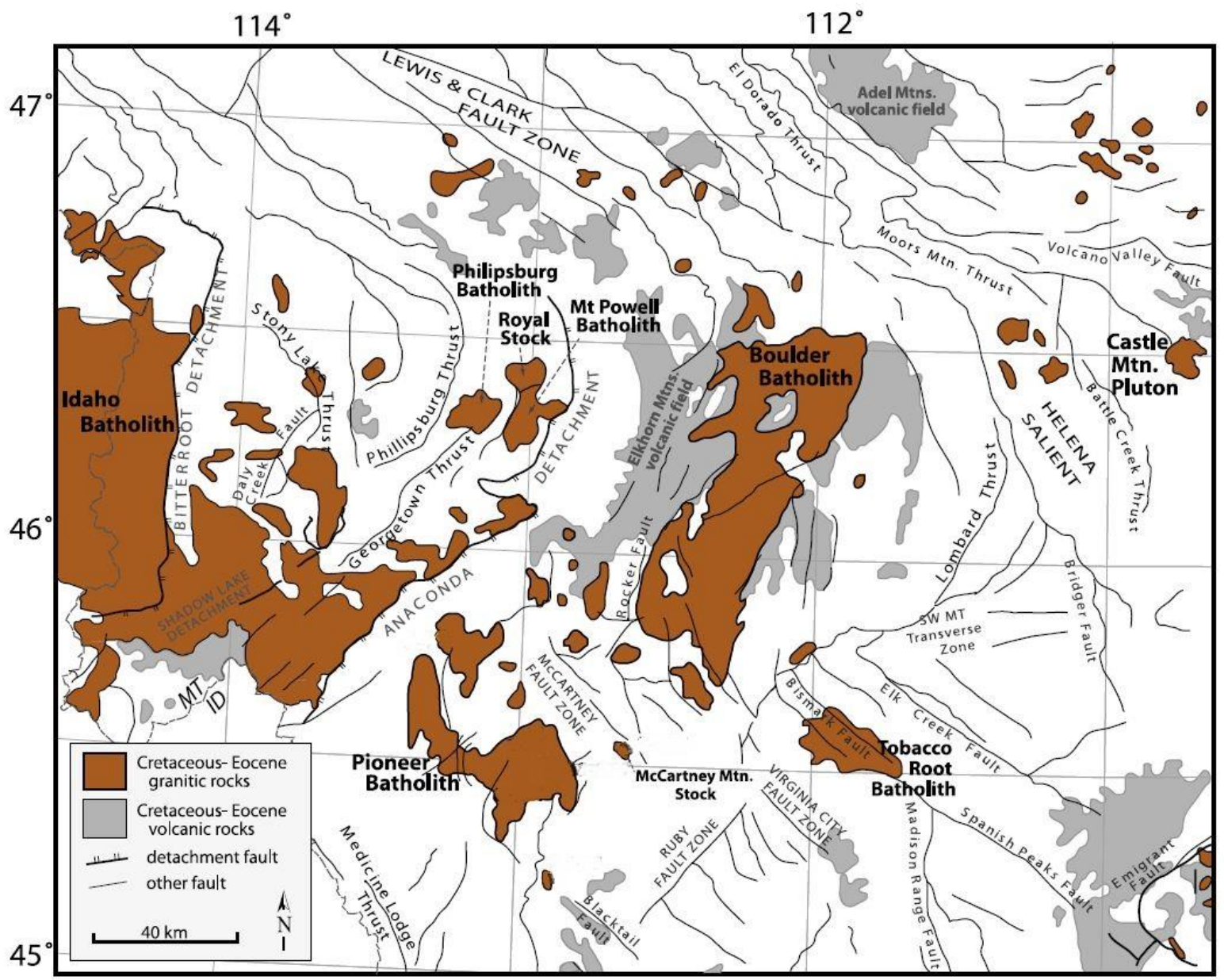

Figure 1 Tectonic map of western Montana. Location of the Idaho, Pioneer, and Boulder batholiths modified from Foster et al., 2012. Thrust sheets west of the Boulder batholith are part of the Sapphire Block that detached along the Bitterroot detachment zone.

The overarching goal of my project is to document the nature of magmatism in the Pioneer batholith and compare it to the magmatism that produced the Boulder batholith to test chemical 
variation models that could reproduce the chemical diversity. To test these models, I have used geochemical data of whole rock samples and petrographic analyses from the Pioneer and Boulder batholiths. As previous authors, I have determined that the batholiths show a typical subduction zone signature with a continental crust involvement with the production of these massive bodies (du Bray et al., 2012; du Bray, Lund, Tilling, Denning, \& DeWitt, 2009; Foster et al., 2012; Lund et al., 2002). More importantly, my analyses show that crystal fractionation is a dominant process in the creation of the magmatic diversity found in these plutonic bodies.

A pending task for future research is to correlate my petrogenetic model to cortical models post-Sapphire block emplacement for the region. Such a correlation will enrich our current understanding for the emplacement of large intrusive bodies with a synchronous magmatic evolution. 


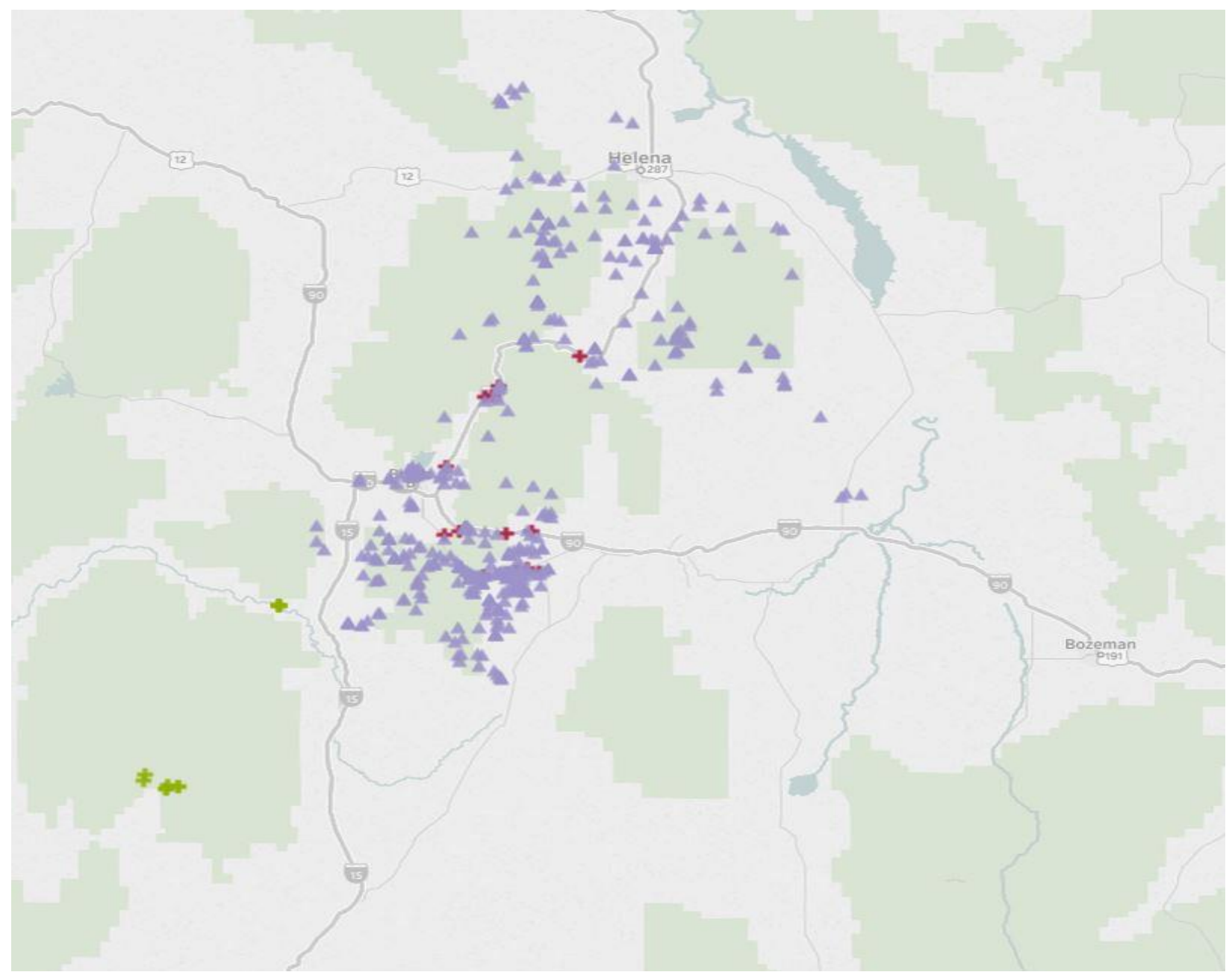

Figure 2 Sample location map.

Map of sample locations, green symbols are from Pioneer batholith, red and purple are from the Boulder batholith. Purple samples coming from du Bray et al., 2012.

\section{TECTONIC SETTING}

The tectonic region that encompasses the Pioneer batholith, Boulder batholith, and the Idaho batholith is a petrologically complex area containing several batholiths and thrust faults, underlined by Precambrian basement rock and capped by sedimentary rocks (Figure 1). Presented in this chapter, is a brief description of the tectonic context and history.

\subsection{Tectonic Context}

Southwestern Montana is in a location that was near the western border of the North American continent and the Pacific Ocean during Cretaceous time. The North American 
Cordillera forms its western border, and the Missouri Plateau borders it to the east. This area is transected by several strike-slip and thrust faults. A succession of uplifted blocks that are characteristically cored by Precambrian metamorphic and igneous rocks, bordered and partially covered by Paleozoic and Mesozoic strata, and divided by intermittent basins of Tertiary and Quaternary deposits, characterizes this area (James \& Hedge, 1980).

One problem associated with the emplacement of these batholiths is how could they be emplaced in a region where crustal shortening, not extension is occurring. The processes leading to the movement of a large intrusive body upward through the crust while creating sufficient room for itself are far from clear. Plate motions, magma moving down deviatoric stress gradients, and the development of structures in an anisotropic material are few factors that may drive the ascent of magma and emplacement (Paterson \& Fowler, 1993). Stoping and roof uplift are two other processes that can lead to pluton emplacement in areas of crustal shortening. The changing tectonic setting of the area may also be a factor leading to emplacement of the batholiths. During Mesozoic time convergence was predominant in the region which later evolved to an extensional setting in late Cenozoic time (Norman \& Leeman, 1989). Another factor leading to emplacement are frontal thrust ramps; thrust ramps facilitate pluton emplacement by providing space at thrust ramp tops (Kalakay, John, \& Lageson, 2001). These thrust ramps are located in the Sevier orogenic belt and were created in Mesozoic time during overall regional contractional deformation (Kalakay et al., 2001).

The batholiths of this region are chemically unique, specially when compared to the Precambrian basement rocks that they are intruding through. The most abundant Precambrian rocks are feldspathic gneiss which are interlayered with amphibolite and metasedimentary rocks (James \& Hedge, 1980). The metamorphic event affecting these rocks was dated at $2.76 \mathrm{Ga}$ 
during the Archean time (James \& Hedge, 1980). The metasedimentary rocks are believed to have been deposited around $3 \mathrm{Ga}$ based on $\mathrm{Sr}$ isotopic ratios and analogy with similar strata in the Beartooth Mountains to the east (James \& Hedge, 1980).

\subsection{General Tectonic History}

The southwestern area of Montana from Late Paleozoic to Late Cretaceous time was located under an epicontinental sea which stretched from the Arctic Ocean down to the Gulf of Mexico, and in places was as much as 1,000 miles wide (Algeo \& Heckel, 2008; Gill \& Cobban, 1973). This Cretaceous sea was bordered on the west by the Cordilleran Highland which separated it from the Pacific Ocean and supplied the sediment deposited in it (Gill \& Cobban, 1973). Upper Cretaceous Elkhorn Mountains Volcanics was the dominant source of sediment along its western shore, which consisted of clastic and pyroclastic material (Gill \& Cobban, 1973). The Cretaceous sea stretched as far east as present-day Iowa which was the location of a stable platform of the Eastern United States (Gill \& Cobban, 1973).

These shallow inland seas accumulated clasts that formed sedimentary rocks which amassed to a thickness of several thousand feet in southwestern Montana. As the Farallon plate collided with the west coast of North America, it compressed the western edge of the North American continent and led to the formation of the Rocky Mountains. The North American continent began to rise, resulting in the retreat of these seas. The thickening of the western edge of the North American continent, caused by the subducting Farallon plate, led to its instability. Thick slices of unstable sedimentary veneer moved eastward along thrust faults creating a broad highland which sets the stage for the later formation of the overthrust belt. The formation of the batholiths in this region is another factor leading to crustal bulging and the instability of the 
sedimentary surface covering this area. This overthrust belt forms the eastern front of the Rocky Mountains from near Helena to the Canadian border. This led to the exposure of Precambrian rocks known as the Belt Supergroup as the younger sedimentary rocks were displaced.

Thrusting associated with the Laramide and Sevier orogenies caused compressional deformation and created considerable relief during the late Mesozoic and earliest Cenozoic eras (Norman \& Leeman, 1989). This now thrusted and folded region of SW Montana was later filled with sediment known as the Renova Formation during Oligocene and early Miocene time; creating the present terrain of ridges of tilted sedimentary rocks with alternating valleys of deposited sediments.

In this region, magma formed due to the subduction of the Farallon plate between 100 and 70 million years ago (Ma). This Cretaceous age subduction of the Farallon plate led to back-arc magmatism which eventually formed several of the batholiths in this region of the United States' northern Cordillera (du Bray et al., 2012; Norman \& Leeman, 1989). Some studies have shown that magma was produced by large-scale mixing of Precambrian crust with subduction-related magmas (Norman \& Leeman, 1989). Oceanic-type mantle variably modified by subduction, and continental crust and subcontinental lithospheric mantle have been identified as possible sources for the batholiths (Norman \& Leeman, 1989). Magmatism happened during the transition from Mesozoic plate convergence to middle and late Tertiary crustal extension in the western United States (Norman \& Leeman, 1989). This change from subduction-related compression to extension-related magmatism contributed to the evolving thermal regime in the crust and mantle (Norman \& Leeman, 1989).

The Farallon plate which was located between the Pacific plate and the North American plate has been mostly consumed due to subduction at its boundary with the North American plate 
(Atwater, 1970). The late Mesozoic Sevier and Laramide orogenies are associated with the collision of the Farallon plate and the North American plate. Some of the processes responsible for this orogeny are still puzzling (English \& Johnston, 2004).

This subduction-related trench was active until about $29 \mathrm{Ma}$ (million years ago) and is mainly associated with the Laramide orogeny occurring in Cretaceous - Tertiary time (Atwater, 1970). The Laramide orogeny, occurring 80 - $55 \mathrm{Ma}$, is associated with the thick-skin tectonics that gave rise to the Rocky Mountains fold-and-thrust belt, characterized by asymmetric fractured uplifts and depressions oriented crudely parallel to the continental margin (English \& Johnston, 2004). The Laramide orogeny postdates the Jurassic and late Early Cretaceous accretion of the terranes that constitute much of the North American Cordillera (Dickinson \& Lawton, 2001).

The Mesozoic batholiths are located west of the Sevier belt, and younger batholiths are found to its east. During Paleogene time a lull in arc magmatism was accompanied by the distinct migration of the inland boundary of arc activity far into the eastern Cordillera where Laramide deformation was simultaneously in development (Dickinson \& Snyder, 1978). The simultaneous decline and migration of the arc magmatism from west to east seem to be directly connected to the consumed slab descending beneath the continent at a shallower angle (Dickinson \& Snyder, 1978).

\subsubsection{Pioneer Batholith}

The Pioneer batholith is located in SW Montana southwest of the Boulder batholith and east of the Idaho batholith. It is a composite batholith consisting of Late Cretaceous igneous rocks exposed over an area of $\sim 800 \mathrm{~km}^{2}$ in and around the Pioneer Mountains (Foster et al., 2012; Hammarstrom, 1982). The age of the plutons of the Pioneer batholith emplacement spans 
from 78 to $65 \mathrm{Ma}$ (Foster et al., 2012). The batholith was emplaced into the allochthonous Mesoproterozoic Belt Supergroup and Paleozoic sedimentary rocks (Foster et al., 2012; Hammarstrom, 1982).

The Pioneer batholith was emplaced at shallow depths within the Laramide-style basement uplifts and Cretaceous Sevier-style foreland fold-and-thrust belt during the diminishing periods of the Laramide orogeny (Foster et al., 2012; Zen, Marvin, \& Mehnert, 1975). The shallowing of the subducting Farallon slab triggered this Late Cretaceous magmatism (du Bray et al., 2012; Foster et al., 2012). Mantle from the asthenosphere most likely instigated partial melting of the Precambrian crust in the region (Foster et al., 2012; Mueller et al., 1996). Its emplacement may have occurred concomitant with the final stage in the emplacement of the Sapphire block.

The iSr values of the Pioneer batholith range from 0.7113 to 0.7160 , indicating extended crustal residence times for the source materials and would seem to discount substantial mantle input of material to the plutonic magmas (Zen, 1996). These iSr values are different from those of the Boulder batholith even though rocks of the two batholiths are chemically and petrographically comparable; they share similar tectonic setting and history and have the same age range (Zen, 1996). Even with these different iSr values, Zen (1996) believed that the Pioneer batholith and Boulder batholith were formed from the same ultimate source.

The Pioneer batholith is in a region where Precambrian crustal provinces converge which constitute a collection of Archean and Proterozoic blocks and orogenic belts that underlie the northern Rocky Mountains (Foster et al., 2012; Foster, Mueller, Mogk, Wooden, \& Vogl, 2006). A relatively continuous, thick $(20-30 \mathrm{~km})$, lower crustal layer underlies the craton (Foster et al., 2012). 
The plutons of the Pioneer batholith have a range of compositions similar to the Boulder batholith but include more mafic compositions. The compositions range from potassic ultramafic rocks, through diorite, tonalite, granodiorite, quartz monzonite and granite (Foster et al., 2012).

\subsubsection{Boulder Batholith}

The Boulder batholith is located due east of the northern part of the Idaho batholith and west of the leading edge of the Cordilleran fold-and-thrust belt (Figure 1). It is sandwiched between the Foreland Basin to the east and the Sapphire Block to the west. The southern edge is marked by a zone of folds and faults that are related to Laramide deformation. The northeastern boundary of the Boulder batholith is dominated by thrusting in the Montana Disturbed Belt. A roof mainly composed of volcanic ejecta covers this shallow slab of granitic rocks (Hyndman et al., 1975).

The Boulder batholith is a plutonic complex consisting of 15 plutons with different compositions. These compositions range from quartz monzonite, granodiorite, and minor syenogranite (du Bray et al., 2012; Hamilton \& Myers, 1974). The plutonic complex of the Boulder batholith is transected by several Eocene rhyolitic and rhyodacitic dikes and small stocks related to the voluminous Lowland Creek Volcanics that cover parts of the batholith (Lund et al., 2002).

The Boulder batholith was emplaced within the foreland of the Late Cretaceous fold-andthrust belt and the Helena embayment of the Mesoproterozoic Belt Supergroup, and reaches a depth of 12 to $18 \mathrm{~km}$ and covers about 4,000 $\mathrm{km}^{2}$ in southwest Montana (du Bray et al., 2012, 2009; Vejmelek \& Smithson, 1995). The Boulder batholith is comprised of the Butte Granite and a set of related less voluminous intrusions that were emplaced in the cogenetic Late Cretaceous 
Elkhorn Mountains Volcanics and Mesoproterozoic to Mesozoic sedimentary rocks during a nine million year span from 81 to 72 million years ago (Ma) (du Bray et al., 2012; Tilling, 1974; Vejmelek \& Smithson, 1995). Most of the Boulder batholith formed during two pulses of magmatism at about $76 \mathrm{Ma}$ and 74.7 million years ago (du Bray et al., 2012).

One major clue to the Boulder batholith's location is believed to be provided by a detached portion of the Idaho batholith known as the Sapphire block. Around 80 Ma mushrooming of the Idaho batholith's infrastructure caused instability in the structure which led to the detachment of the Sapphire block (Hyndman et al., 1975). As the Sapphire block separated from the Idaho batholith, it moved $\sim 25 \mathrm{~km}$ east during the same time the Boulder batholith started to form (Hyndman et al., 1975). This caused the injection of the Boulder batholith to spread eastward from beneath the Sapphire block (Hyndman et al., 1975). This is one explanation for how the Boulder batholith could be genetically related to batholiths to the west (i.e. Pioneer batholith) given its somewhat isolated location.

Another control of emplacement is east-west tear faults which were active throughout Late Cretaceous thrust faulting during times of tectonic convergence (Lund et al., 2002; Norman \& Leeman, 1989). Emplacement of the remaining Boulder batholith plutons occurred during a 6 10 m.y. span at around 81.7 to 73.7 Ma during eastward thrusting in the fold-and-thrust belt (du Bray et al., 2012; Vejmelek \& Smithson, 1995). Chemical and petrographic data do not relate to the idea of the Butte Granite entailing separate, compositionally discrete intrusions (du Bray et al., 2012). This notion is still left up to debate whether the Boulder batholith formed in a single magmatic event or two pulses of magmatism.

The regional structural setting surrounding the Boulder batholith is another important factor affecting its emplacement. The most prominent factors of this setting are the pattern of 
long-term activity of Late Cretaceous fault sets, the magma source and the positions of principal tectonic provinces relative to the plutons (Schmidt, Smedes, \& MichaelO’Neil, 1990).

The boundary of two Late Cretaceous tectonic provinces are straddled by the Boulder batholith and its satellite plutons: the Rocky Mountain foreland and the Cordilleran thrust belt (Schmidt, Smedes, \& MichaelO'Neill, 1990). The Cordilleran thrust belt located in southwestern and west-central Montana lies north and west of the Rocky Mountain foreland. Middle Proterozoic and Phanerozoic sedimentary rocks, as well as pre-batholith Late Cretaceous volcanic rocks, comprise the thrust belt and were transported east-northeasterly (Schmidt et al., 1990). The thrusts are rooted at or near the base of a 3km-thick prism of Middle Proterozoic rocks of the Belt Supergroup in one or more decollement horizons (Ruppel, Wallace, Schmidt, \& Lopez, 1981). This decollement represents the floor of the batholith, and much of it was emplaced on this surface as the allochthonous sedimentary rocks were being translated eastwardly (Schmidt et al., 1990).

The emplacement of the Boulder batholith was also controlled by three major fault sets. The three fault sets that cross the upper crust in the region of the Boulder batholith have been recurrently active since the Proterozoic: they consist of NE-trending, E-trending, and NWtrending fault sets (Schmidt et al., 1990). These faults are believed to have controlled the emplacement of the early-stage plutons and the Butte Granite which occurred concurrently (Berger et al., 2011).

The magma source of the Boulder batholith is believed to come from the subduction of the Pacific (Farallon) plate eastward beneath the North American plate. Given the location of the Boulder batholith, a subduction-related origin well east of the Late Cretaceous western margin of North America would require a fast convergence rate and consequent shallow subduction (du 
Bray et al., 2012, 2009). Radiogenic isotope data correlate with this theory plus an idea of substantial mantle components involvement (du Bray et al., 2012). As the Farallon plate subducted, it gave rise to molten basalt and volatiles which melted the lower part of the continent. The crustal composition that melted first was granite which then began to rise. This lead to the formation and emplacement of the Boulder batholith at around 73 to $81 \mathrm{Ma}$.

Volcanism, plutonism, folding and thrusting started and stopped inside a few million years of each other during the last 20 m.y. of the Cretaceous (Robinson, Klepper, \& Obradovich, 1968). Major folding is thought to have ended after volcanism ceased (Robinson et al., 1968).

\subsubsection{Idaho Batholith}

Immense quantities of granite magma melted deep within the large welt that formed along the old continental margin between 100 and $44 \mathrm{Ma}$. This welt was formed from the contraction caused by the Farallon plate subducting under the North American plate during Mesozoic and early Tertiary times (Foster, Schafer, Fanning, \& Hyndman, 2001). The largest single component of the Idaho batholith is the Atlanta lobe, which is a voluminous peraluminous suite formed between 83 and 67 Ma (Gaschnig, Vervoort, Lewis, \& McClelland, 2010).

Precambrian continental crust was intruded by a large portion of the Idaho batholith which led to the melting of this ancient crust producing large peraluminous granitic rocks (Mueller \& Shuster, 1995). Geochemical data correlate with the involvement of Precambrian continental crust as well as subduction-related magma as a source for the Idaho batholith (Norman \& Leeman, 1989).

Melting occurred at around 15 miles below the surface and crystallization began at a depth of 10 miles below the surface, emplacement at this depth led to a slow cooling process (Hyndman, 1984). The outcome of these processes is now visible throughout a large region of 
central Idaho and in the Bitterroot Range of western Montana. A less voluminous portion of the Idaho batholith developed over Phanerozoic accreted terranes on its western margin (Foster et al., 2006). Foster et al. (2001, 2006) presented varied source magmas for the Idaho batholith but identified the Precambrian crust as a major component.

Compared to other Mesozoic-Tertiary batholiths in the North American Cordillera orogen, the Idaho batholith is unique since it intruded thick Precambrian crust (Foster et al., 2006). These Precambrian rocks are part of the Belt Supergroup and chemical, petrologic, and field data suggest that this part of the batholith formed from magmas created by subduction along the western margin of North America at around 50 -100 Ma (Mueller \& Shuster, 1995). They were emplaced along and to the west of the major terrane boundary separating continental rocks from accreted oceanic-arc terranes (Mueller \& Shuster, 1995). This boundary is identified by the transition from accreted oceanic-arc terranes of the Blue Mountain Province to continental-margin sedimentary rocks of Proterozoic or Paleozoic age (Mueller \& Shuster, 1995).

The large quantities of molten magma within the welt made the continent unstable along the old western margin. This led to large chunks detaching and moving eastward from this former mountain range.

Enormous volumes of peraluminous granitoids, containing biotite granitoids, cored by a muscovite-biotite granite dominate the Idaho batholith (Gaschnig et al., 2010). 


\subsection{General lithological background}

The study area includes igneous rocks of the three batholiths, underlain by Precambrian igneous and metamorphic rocks, capped by Paleozoic to Cenozoic strata of sedimentary and volcanic rocks and separated by intermittent Tertiary and Quaternary basin deposits.

\subsubsection{Regional Basement}

The regional basement in southwestern Montana is composed of several igneous and metamorphic rock types. The most dominant type is quartzofeldspathic gneiss of diverse composition (James \& Hedge, 1980) with interlayers of amphibolite and metasedimentary rocks, dolomitic marble, quartzite, and iron-formation (James \& Hedge, 1980). Rb-Sr analyses limit the age of metamorphism to $2.7 \mathrm{Ga}$ (James \& Hedge, 1980). These Precambrian rocks outcrop throughout the region.

\section{METHODS}

\subsection{Pioneer and Boulder Batholith sample collection}

Ten to thirteen samples were collected over an area of $6,000 \mathrm{~km}^{2}$ from the Boulder and Pioneer Mountain batholiths. At selected outcrops, the method of sampling was to obtain an extensive variety of rocks based on their physical characteristics. For the Pioneer and Boulder batholiths sample selection was designed to gather an array of rocks with varying mineral composition, grain size, color, and phenocrysts. Samples were collected from natural outcrops from similar locations as identified by du Bray et al., (2009)

\subsection{Bulk geochemical analysis}

For the bulk geochemical analyses of major- and trace-elements over 20 samples were selected. Only the unweathered samples were chosen for geochemical analysis, using thin section 
and hand samples observations to identify weathered samples. Both Laser Ablation Inductively Coupled Plasma Mass Spectrometry (LA-ICP-MS), and X-ray fluorescence (XRF) analyses at Michigan State were completed on fused glass disks. The procedure followed the outline described by Hannah et al. (2002) for the preparation of low-dilution fusion glass disks (LDF). The fused disks were analyzed using a Bruker Pioneer S4 X-Ray fluorescent spectrograph. XRF element analyses were reduced using Bruker Spectra Plus software®, which uses fundamental parameters (Criss, 1980).

For LA-ICP-MS trace element analyses, a Cetac+ LSX200 laser ablation system coupled with a Micromass Platform ICP-MS was used. The analyses were done for approximately three minutes with continuous ablation (line scan). To correct for variations in ablated sample volume and instrument response strontium, determined by XRF, was used as an internal standard. MassLynx ${ }^{\circledR}$ software was used for trace element data reduction. The background signal from the argon plasma was subtracted from each of the samples and standards before any calculations were done. Based on a linear regression method using BHVO, W-2, JB-1, JB-2, JB-3, JA-2, JA3, BIR, QLO-1, and RGM-1 standards, element concentrations in the samples were calculated. For the final calibration line for samples only standards with calculated values within $15 \%$ of the ideal standard values were used.

Petrographic microscope analyses were performed on thin sections made to a thickness of 2 microns. An Olympus BX40 Trinocular Microscope was used for the analyses of thin sections under plane- and cross-polarized light. Mineral proportions were estimated using a glass coverslip with tick marks along with field of view calculations. 


\section{RESULTS}

\subsection{Geochemistry of Pioneer Mountain Batholith}

In the figures, all the major elements have been normalized to $100 \%$.

\subsubsection{Major elements}

The LeBas et al. (1986) chemical classification of samples from the Pioneer batholith is shown in Figure 3. The samples plot in the dacite and basalt fields with one sample in the rhyolite field and one sample in the basaltic-andesite field. There are no transitional compositions and all but one plot in the calc-alkaline field. The sampled rock ages range from 70-76 Ma, the dacites are granites, and basalt plots are monzonites.

The major- and trace-element data are presented in variation diagrams in Figures 4 and 5, respectively. Samples from the Pioneer Mountain batholith show significant chemical variation. The largest distinctions are observed in $\mathrm{Na}_{2} \mathrm{O}, \mathrm{MgO}, \mathrm{Al}_{2} \mathrm{O}_{3}$, and $\mathrm{K}_{2} \mathrm{O}$. The major oxides for the dacite and basaltic samples follow a relatively smooth trend which would suggest that they are genetically related. There is a noticeable gap in relation to $\mathrm{SiO}_{2}$ spanning from $\sim 57-67 \mathrm{wt}$. \% $\mathrm{SiO}_{2}$ (intermediate compositions). 


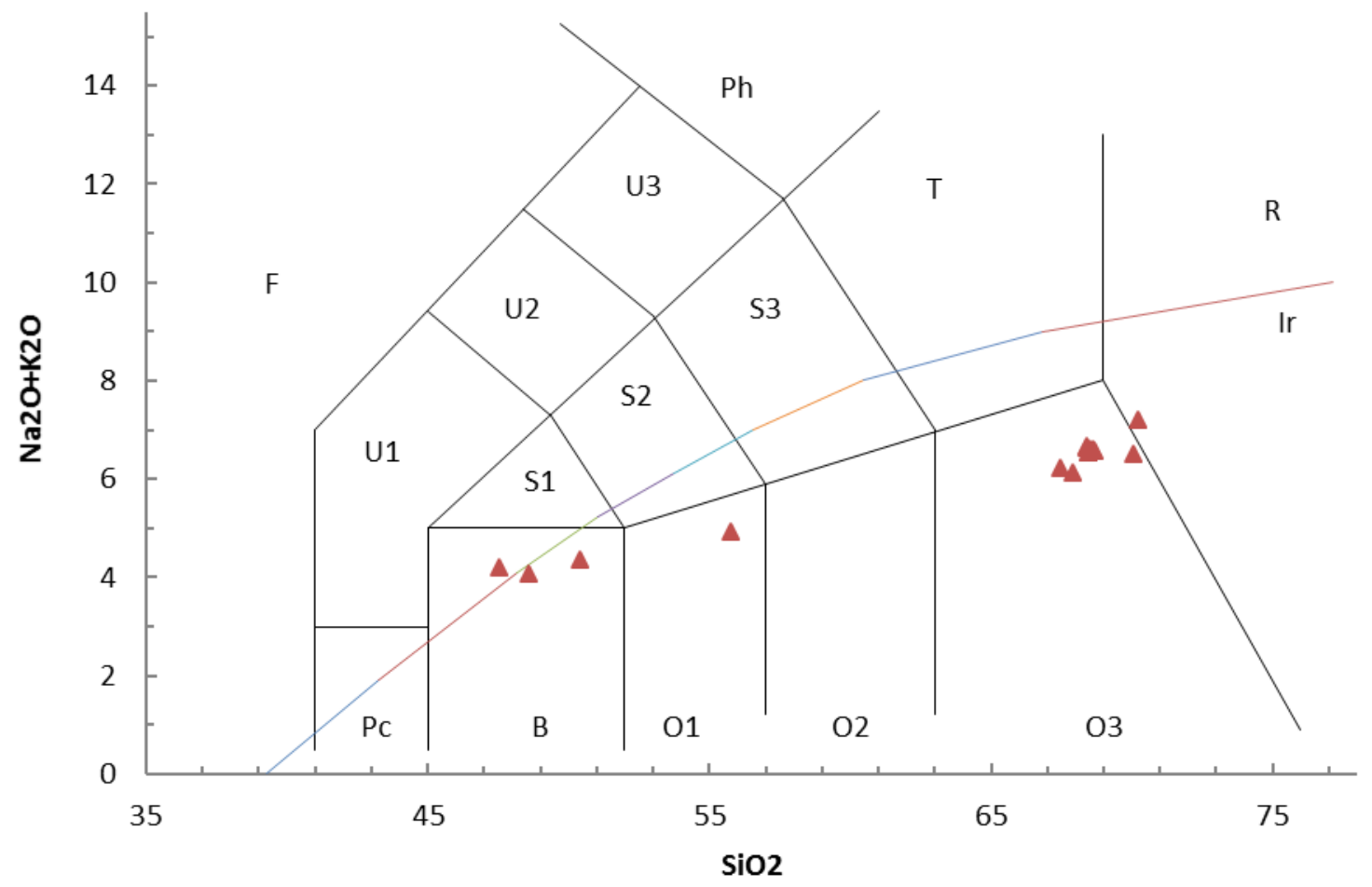

Figure 3 TAS diagram from Le Bas et al., (1986) showing Pioneer batholith sample plots. Most samples plot within the basalt and dacite fields with one sample plotting in the basaltic-andesite field and one sample plotting the rhyolite field. 

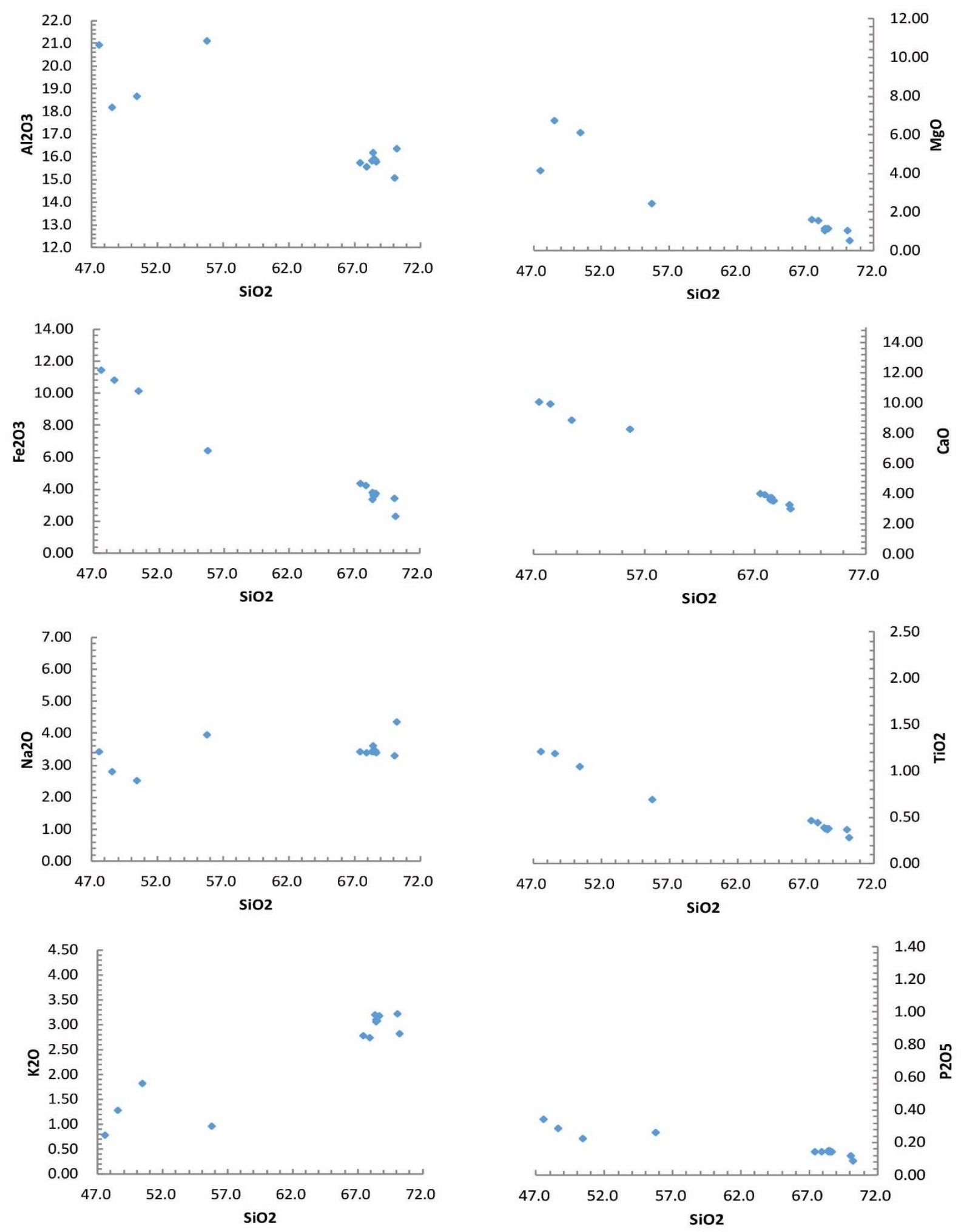

Figure 4 Bulk rock geochemistry. Harker variation diagrams plotting major oxides vs. $\mathrm{SiO}_{2}$. Noticeable decreases in $\mathrm{CaO}$ correlate to amphibole fractionation along with increasing $\mathrm{Al}_{2} \mathrm{O}_{3}$ then decrease with increasing silica content. 


\subsubsection{Trace elements}

Trace element variation diagrams with respect to $\mathrm{SiO}_{2}$ are presented in Figure 5. Most trace elements show slight chemical variation in the Pioneer batholith except for $\mathrm{Cr}$, Hf, Sr, and $\mathrm{Zr}$. The high $\mathrm{Zr}$ and $\mathrm{Hf}$ concentrations in the more evolved melts suggest extensive liquid evolution. Some high $\mathrm{Cr}$ levels could be due to analytical error or crystal accumulation. The reduction in $\mathrm{Sr}$ in the more evolved melts could be due to plagioclase fractionation, which will be explored further in the discussion section of this paper. There is a noticeable increase in $\mathrm{Rb}$ and $\mathrm{Ba}$ which are the more mobile LIL elements, and this could suggest contamination by a crustal component. This crustal component has been shown to a be a product of asthenosphere mantle initiating melting of the Precambrian crust leading to magmatism (Foster et al., 2012; Mueller et al., 1996). Investigations by Zen et al. (1980) also corroborate this theory, suggesting that $\mathrm{Rb} / \mathrm{Sr}$ ratios show a Precambrian crustal component and are a good candidate for the source of granitoids on isotopic grounds. The low concentrations of $\mathrm{Rb}$, Th, and $\mathrm{U}$ in the mafic members which also have $\mathrm{Sr}$ and $\mathrm{Ca}$ concentrations suggest an M-type granitoid which could be the outcome of single-stage fractionation of mantle melts. 

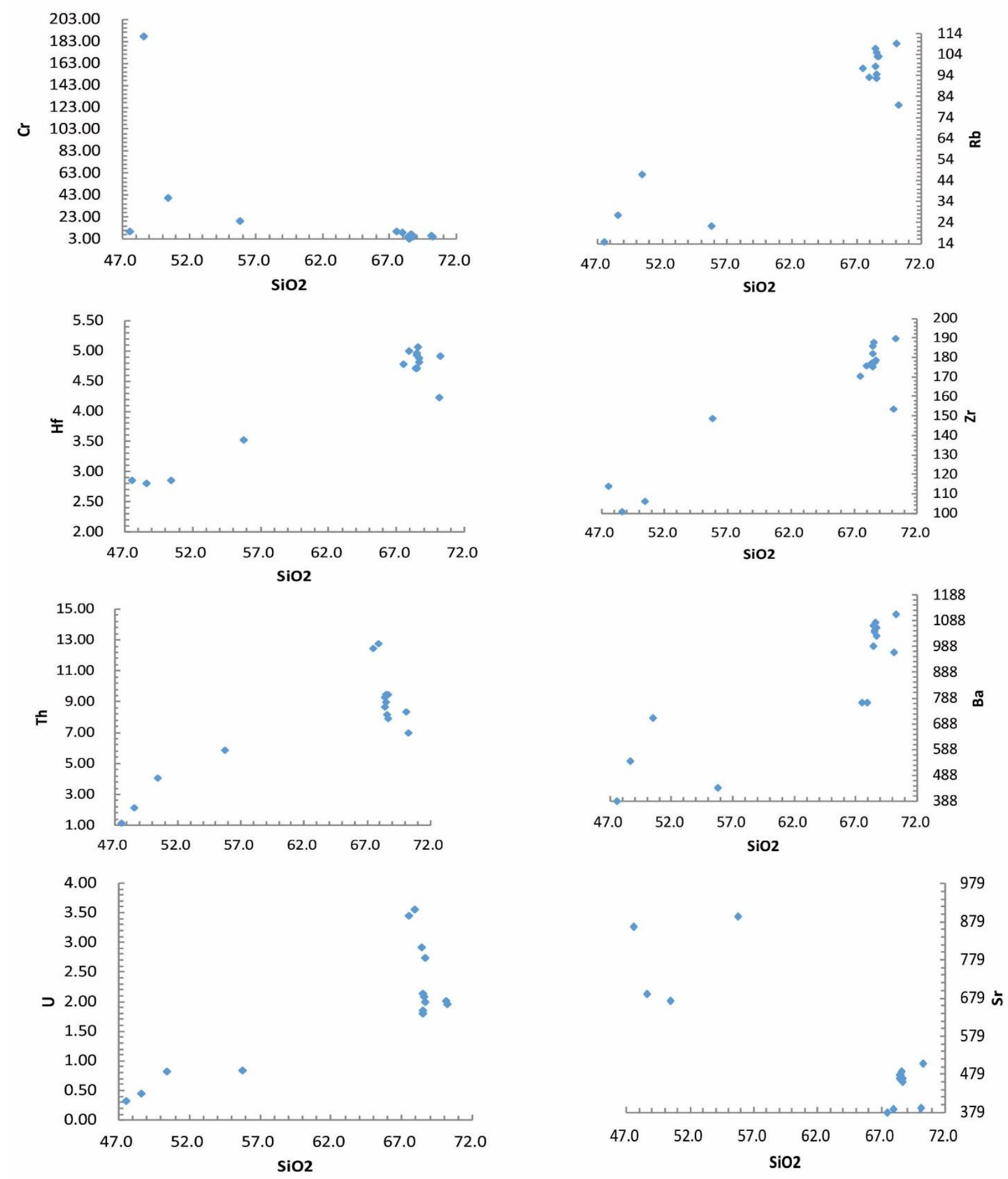

Figure 5 Trace Element Harker diagrams. Pioneer batholith trace element samples plotted vs. $\mathrm{SiO}_{2}$. Sr decreases with increasing $\mathrm{SiO}_{2}$ content, evidence for plagioclase fractionation. Ba and Rb increase are an indication of crustal contamination. All trace elements are presented in ppm. 
Spider diagrams and rare earth element (REE) diagrams for the Pioneer batholith are shown in Figure 6. The spider diagram shows a Nb-Ta trough and the decoupled large ion lithophile elements/high field strength elements (LIL/HFS) pattern which is considered a characteristic of subduction zone magmas. More evolved Pioneer batholith rocks show elevated $\mathrm{Ta}, \mathrm{Nb}, \mathrm{Zr}$, and $\mathrm{HF}$ which is a good indicator of the involvement of subcontinental lithospheric mantle for the silica-rich Pioneer samples. The Sr spike in the mafic components represents plagioclase accumulation. The silicic components show a slight peak and trough in some samples for Sr.

The REE diagram shows the distinct geochemical properties between the mafic and silicic rocks of the Pioneer batholith. The silicic components are enriched with respect to the mafic group in the LREE meaning fractionation could be a dominant process, and both groups would be considered enriched which could mean continental crust involvement in this enrichment. The REE for both the silicic and mafic batholith samples have an enrichment of LREEs over HREEs which is similar to other subduction-related magmas. The spoon shape of the HREEs shown in the REE diagram is consistent with the fractionation of amphibole (du Bray et al., 2012, 2009; Hammarstrom, 1982). There is an Eu trough in the silicic group which could represent fractionation of plagioclase. 

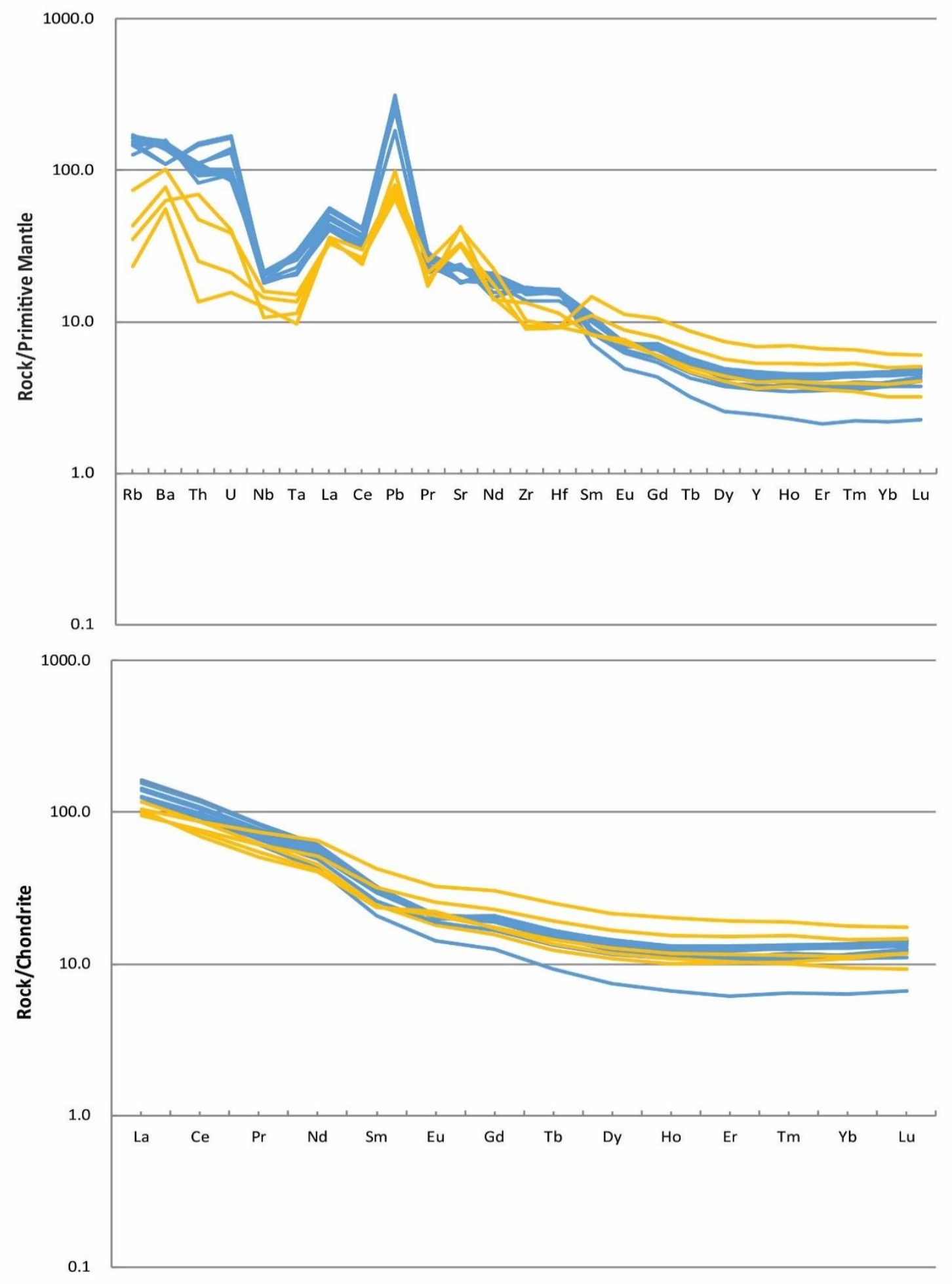

Figure 6 REE \& Spider diagrams. Blue lines represent silicic samples, and yellow lines represent mafic samples for the Pioneer batholith. Eu peaks in mafic samples and troughs in silicic sample indicate plagioclase accumulation and fractionation, respectively. The "spoon-like" shape of the REE diagram is evidence for amphibole fractionation. 


\subsection{Petrographic analyses of Pioneer batholith end members}

Petrographic analyses were performed on eleven thin sections representing two end members of the Pioneer batholith. The mafic end member is a monzonite, and the felsic end member is granite. Complete petrographic analyses for all the units can be found in the Appendix.

\subsubsection{Monzonite}

The monzonites of the Pioneer batholith alkaline basalts with a few samples plotting in the basalt-andesite fields of the TAS diagram (Fig. 3). Primary mineralogy of the monzonite consists of plagioclase (45\%), amphibole (30\%), and biotite (15\%) with a matrix of quartz and opaques. Plagioclase crystals show albite twinning, compositional zoning, and sieve textures. Plagioclase accumulation with interstitial quartz grains is shown in thin section (Figure 7); this is congruent with the Eu peaks in REE diagrams. Amphibole mineral grains have a poikilitic texture and larger elongate grains common with longer cooling periods. In Figure 8 they are shown in with intergrowths of plagioclase.

Amphibole is the main mafic mineral of the assemblages and occurs in a significant proportion along with biotite. Amphiboles dominate these mafic samples, and as they progress to a higher silica content, the amphiboles are less abundant. This is consistent with amphibole fractionation and is shown in the REE diagram above (Fig. 6) due to the affinity of MREE with amphibole explaining the "spoon" shape. 


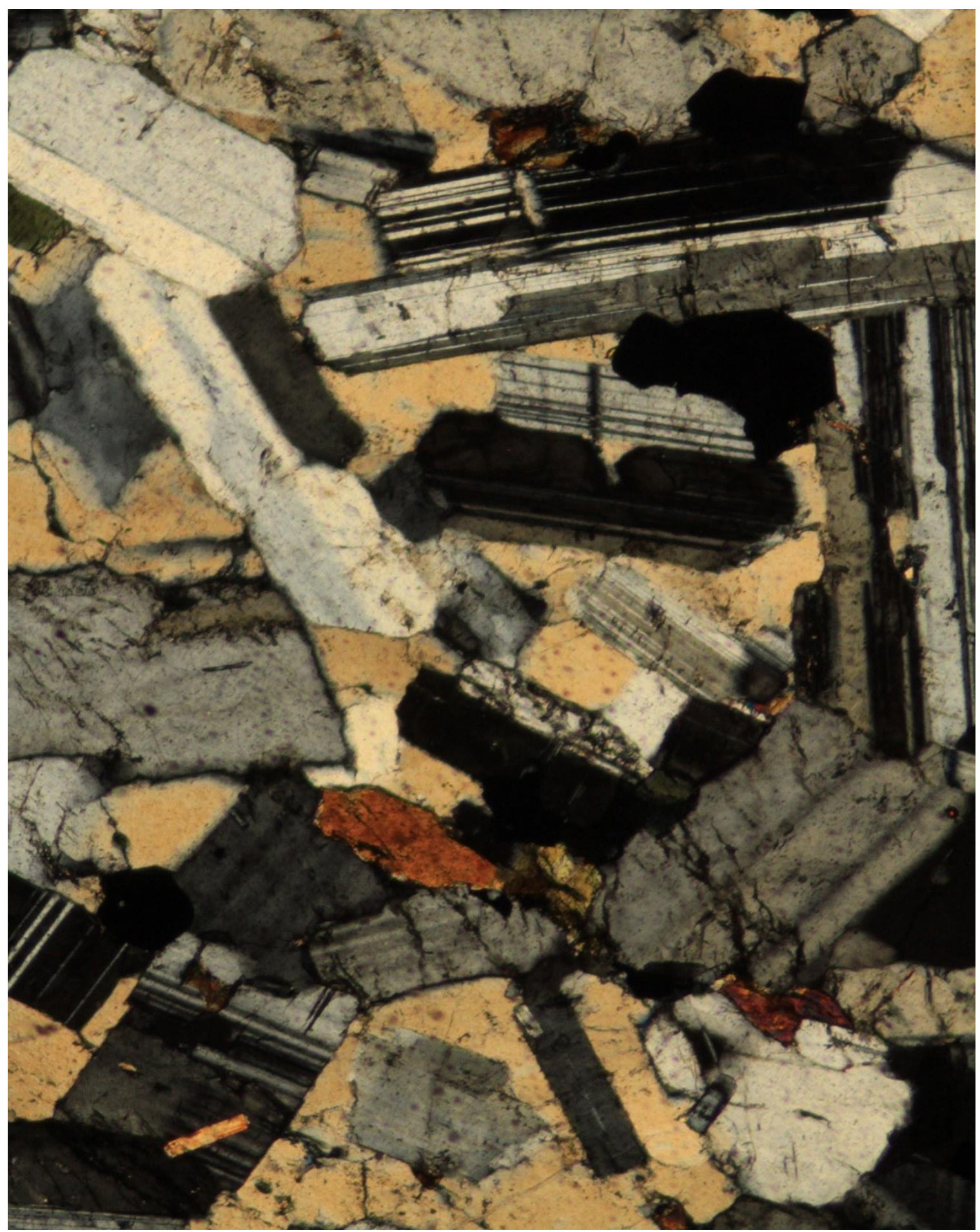

Figure 7. Thin section of Pioneer batholith sample 002. Noticeable plagioclase accumulate texture with interstitial quartz grains. Thin section under cross-polarized light. 


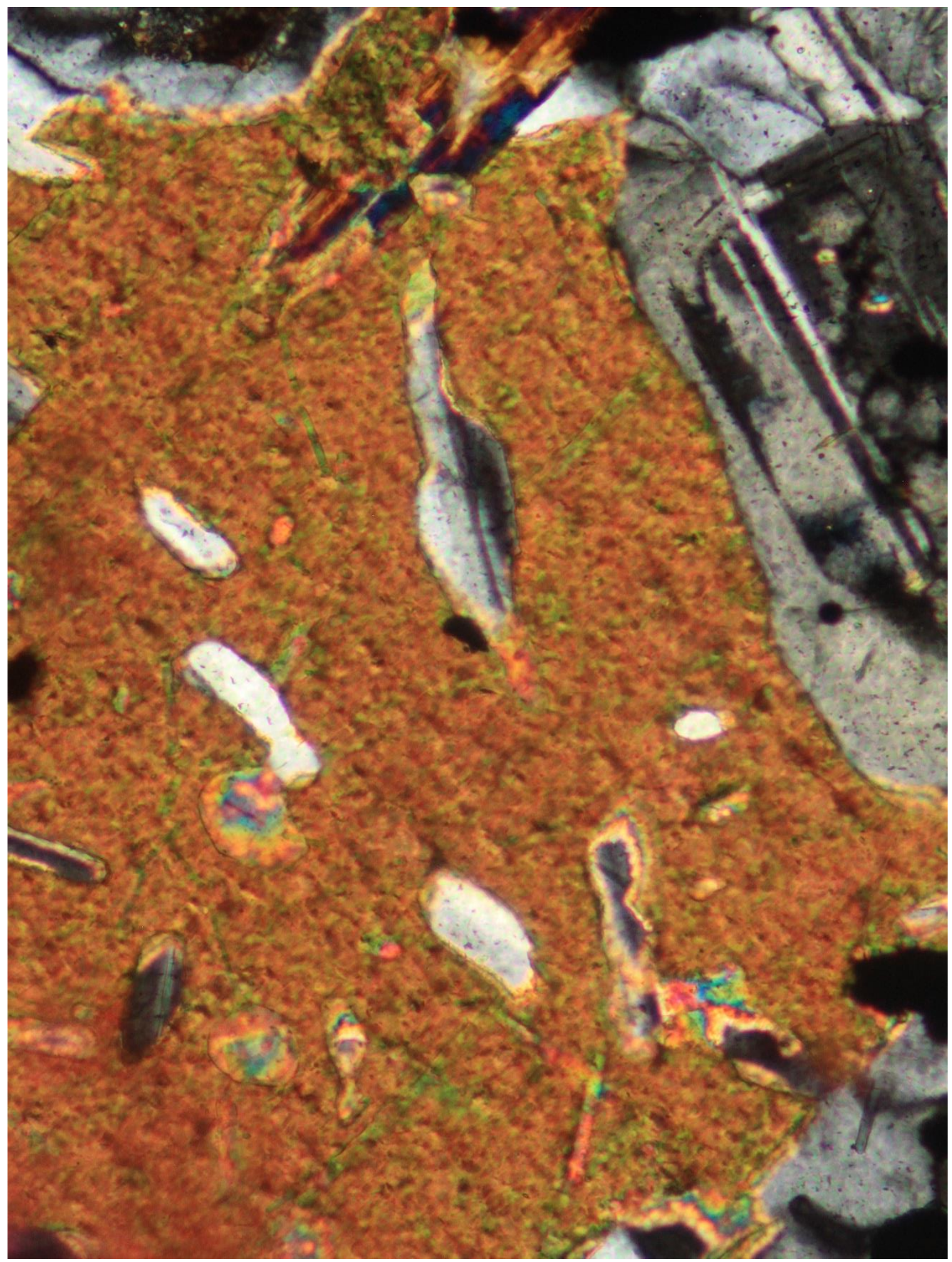

Figure 8 Thin section of Pioneer batholith sample 001. Amphibole pictured with intergrowths of plagioclase. Thin section is under cross-polarized light. 


\subsubsection{Granite}

Granites of the Pioneer batholith are crystalline and range from coarse to fine grained. These rocks are alkaline dacites, with a few samples extending into the rhyolite field. Detailed microscope work on the most evolved Pioneer batholith samples revealed that they are entirely free of entrained cumulate material and have much smaller proportions of amphibole and plagioclase.

Petrographically, the granites have abundant potassium feldspar (45\%), plagioclase (20\%), and quartz $(\sim 15 \%)$ with biotite $(10 \%)$ and amphibole $(5-10 \%)$. Textures range from medium subhedral and anhedral granular to coarse-grained granular to porphyritic. Porphyritic granites are shown in Figure 9, large individual grains of plagioclase, amphibole, quartz are surrounded by a groundmass of quartz and plagioclase.

\subsubsection{Relationship between the Monzonite and Granite}

The monzonites and the granites have similar patterns of REE even with the minor enrichment of the later in most trace elements. Despite the contrasting concentrations of major elements, we can still infer from the REE diagrams that these units share similar parental magmas (e.g. $\mathrm{MgO}, \mathrm{SiO}_{2}, \mathrm{Fe}_{2} \mathrm{O}_{3}, \mathrm{CaO}$, etc.) observed in these units (Figs. 4 \& 6).

Plagioclase and amphibole are pervasive in the monzonites and to a lesser extent the granites which are indicative of a shared origin. The reduction of plagioclase and amphibole concentrations from the monzonite to granite in thin section along with REE patterns allow us to recognize a possible fractionating assemblage that can be used to model the magmatic variation detected in the Pioneer batholith. 
The gap in $\mathrm{SiO}_{2}$ content between the monzonites and granites can be caused with only a minor amount of fractional crystallization. This occurrence can be explained by the Daly gap which reflects the dynamics of fractional crystallization and the phases involved.

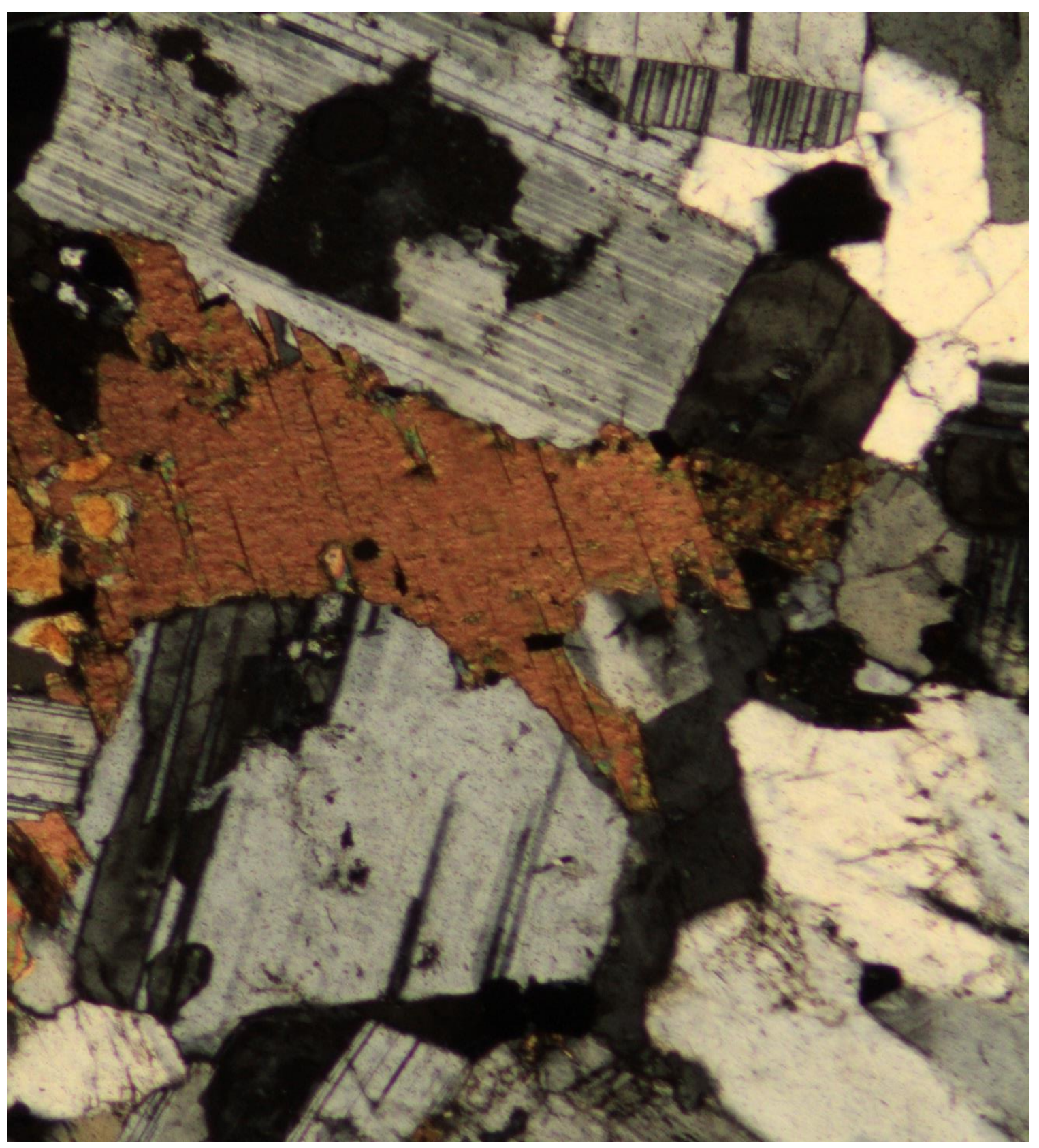

Figure 9 Thin section of Pioneer batholith sample 001. Large grains of plagioclase with albite twinning and amphibole are present with some interstitial quartz grains. Thin section is under cross-polarized light. 


\section{DISCUSSION}

The goals of this study are to document the nature and source of the Pioneer batholith and compare it with the Boulder batholith; both are associated with the subduction of the Farallon plate. Another goal is to propose a magmatic evolution model for the Pioneer and Boulder batholiths.

\subsection{Chemical and mineralogical variation of SW Montana batholiths}

The emplacement dates for the Pioneer, Boulder, and Idaho batholith overlap, ranging from 78-73 Ma. This section presents a discussion of chemical and mineralogical evidence suggesting that the Pioneer batholith and Boulder batholith were produced from the same parent material. Fractionation modeling, variation diagrams, thin section analysis, geochemical data, REE, and Spider diagrams were used and cross-referenced to produce evidence for the similar sources for the Pioneer and Boulder batholiths.

The spectra observed for the post-intrusive Lowland Creek Volcanics associated with the Boulder batholith are similar to initial strontium ratios for the Pioneer batholith, which range from 0.7064-0.7098 (Hammarstrom, 1982). The Sr ratios indicate a crustal components interaction with the melt produced from the subducting Farallon plate for both the Pioneer and Boulder batholith. This is one identifying factor suggesting that they are from the same source.

The TAS diagram (Figure 10) shows Boulder batholith samples plotting within the range of the Boulder batholith samples from du Bray et al., 2012. The silica-rich Pioneer batholith samples plot within the range of Boulder batholith samples from du Bray et al., 2012 as well. Pioneer batholith samples all plot within the Idaho batholith sample range suggesting that they are compositionally homogeneous. The Pioneer batholith samples plot in the basalt, basaltic andesite, and dacite fields with a noticeable gap of andesite compositions. 


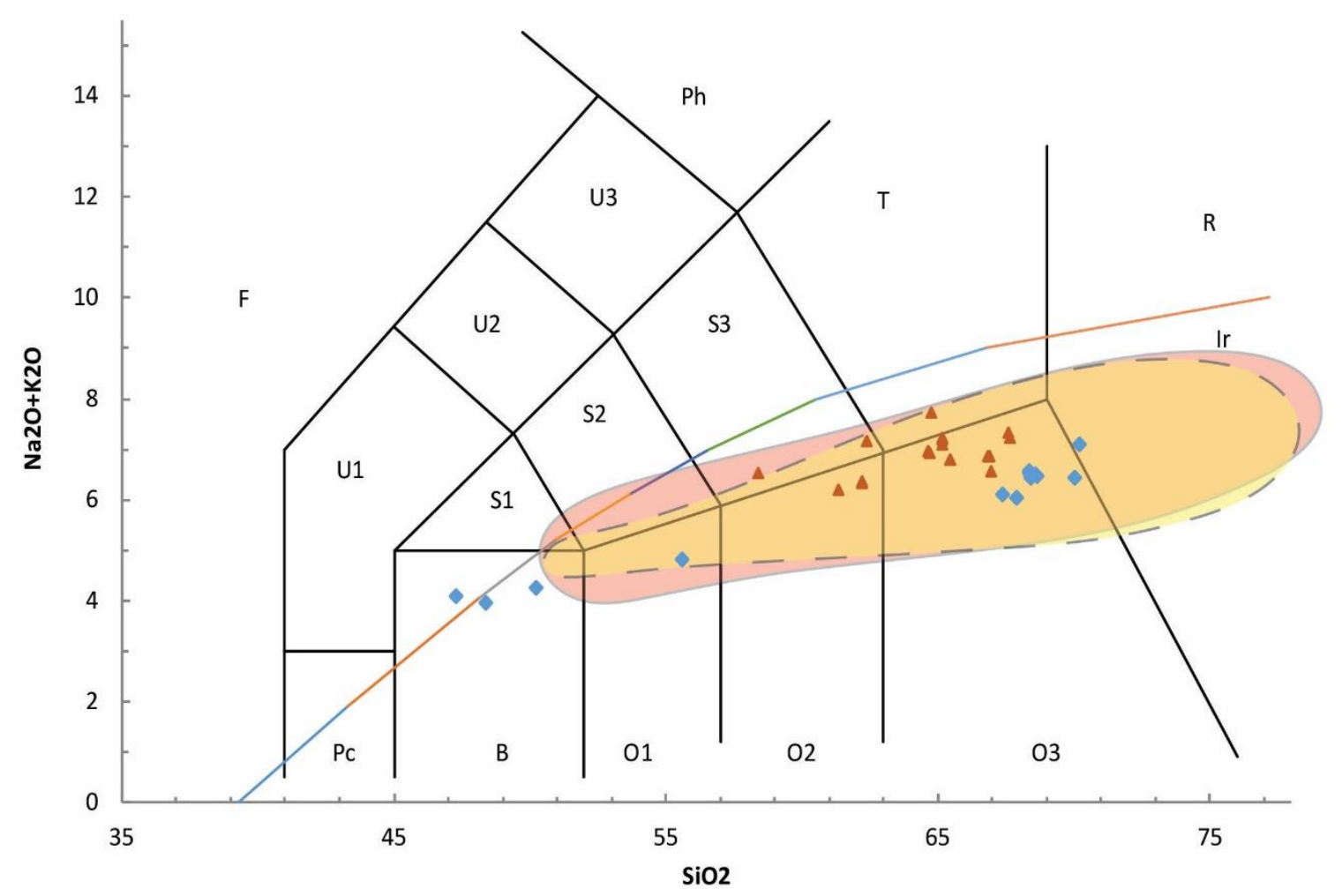

Figure 10. TAS diagram, all samples. Blue diamonds are Pioneer batholith samples; red triangles are Boulder batholith samples. Yellow blob represents Idaho batholith sample field from Clarke, 1990 and red blob represents the Boulder batholith sample field from du Bray et al., 2012.

If a smooth curve is drawn on the $\mathrm{Al}_{2} \mathrm{O}_{3}$ diagram, $\mathrm{Al}_{2} \mathrm{O}_{3}$ increases until about 57 wt. $\% \mathrm{SiO}_{2}$ and then decreases. Comparing this to the $\mathrm{CaO}$ variation diagram, $\mathrm{CaO}$ decreases continuously showing possible clinopyroxene fractionation early on, removing $\mathrm{Ca}$ and not $\mathrm{Al}$, and later as plagioclase began to crystallize it removed both $\mathrm{Al}$ and $\mathrm{Ca}$. The trends in these diagrams possibly suggest fractional crystallization of plagioclase, amphibole, and apatite.

Figure 11 presents the Harker variation diagrams for the Pioneer and Boulder batholiths. When viewed together they show a smooth trend which suggests a comagmatic relationship between the two batholiths. The Pioneer batholith samples are bimodal, comprised of silicic and 
mafic compositions while the Boulder batholith fills most of the intermediate composition gaps with some overlap of silicic within the silicic samples.
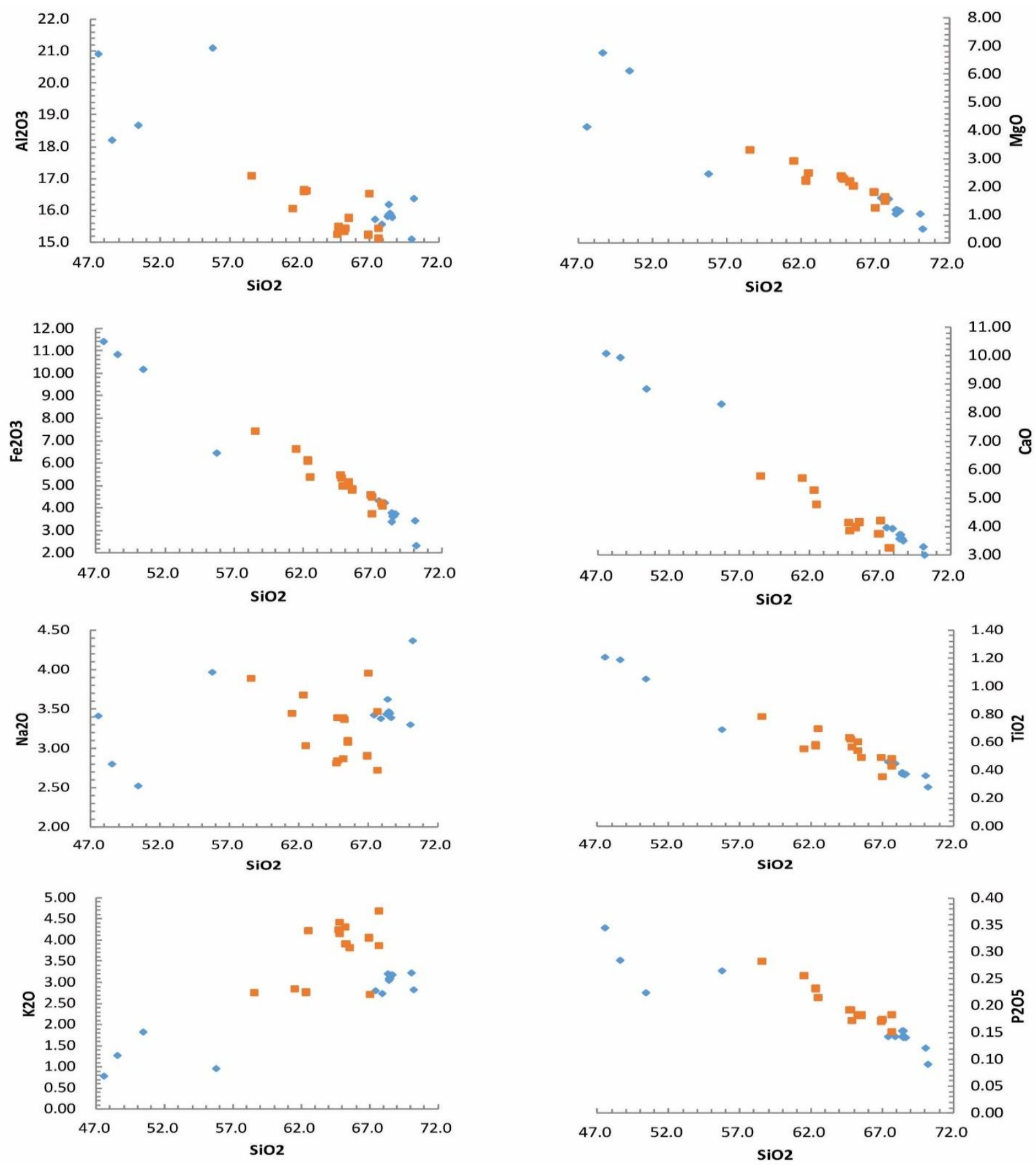

Figure 11. Harker variation diagrams. Blue diamonds represent the Pioneer batholith and orange squares represent the Boulder batholith samples. Boulder batholith samples follow a smooth trend in line with the Pioneer samples and bridge the gap between the low and high silica members. 
The Pioneer and Boulder batholith samples both have geochemical signatures similar to subduction zone magmas, showing enrichment in large ion lithophile elements (LILE) relative to high field strength elements (HFSE) and light earth elements (LREE). They both have $\mathrm{Nb}$ and Ta troughs which imply a subduction-related source and possibly amphibole fractionation. Figure 12 shows Spider and REE diagrams comparing the Pioneer batholith to the Boulder and Idaho batholith samples. The high silica Pioneer batholith samples show little variation from the high silica Boulder batholith trace elements suggesting a similar parent material. Both have elevated $\mathrm{Hf}-\mathrm{Zr}$ which could imply extensive liquid evolution or an enriched source material. The source for both batholiths is believed to be the interaction of the Farallon plate with crustal components as it subducted beneath the North America Plate in Late Cretaceous.

We have established that the Pioneer and Boulder batholiths are likely derived from the same parent magma, a statement reinforced by their comparable REE patterns (Figure 12) and similar mineralogy. This realization permitted us to test for crystal fractionation as the key process driving magmatic evolution between the two batholiths. Fractionation modeling using a calculated parent material for the Pioneer batholith shows that plagioclase and amphibole are the main phases that fractionated from the melt. This can be directly correlated to thin section analysis, Spider, REE, and variation diagrams (Figures 11, 12, 13, 14, 15).

Diagnostic trace elements from the Pioneer batholith (Dy, Yb, La) are also consistent with the fractionating assemblage being dominated by plagioclase and amphibole. Amphibole appears throughout the magmatic differentiation process - as evidenced by thin section observations and REE diagrams, and thus amphibole fractionation is one key component in our modeled crystal fractionation schemes. Specifically, we have shown that amphibole fractionation $(\sim 37 \%$ of the 

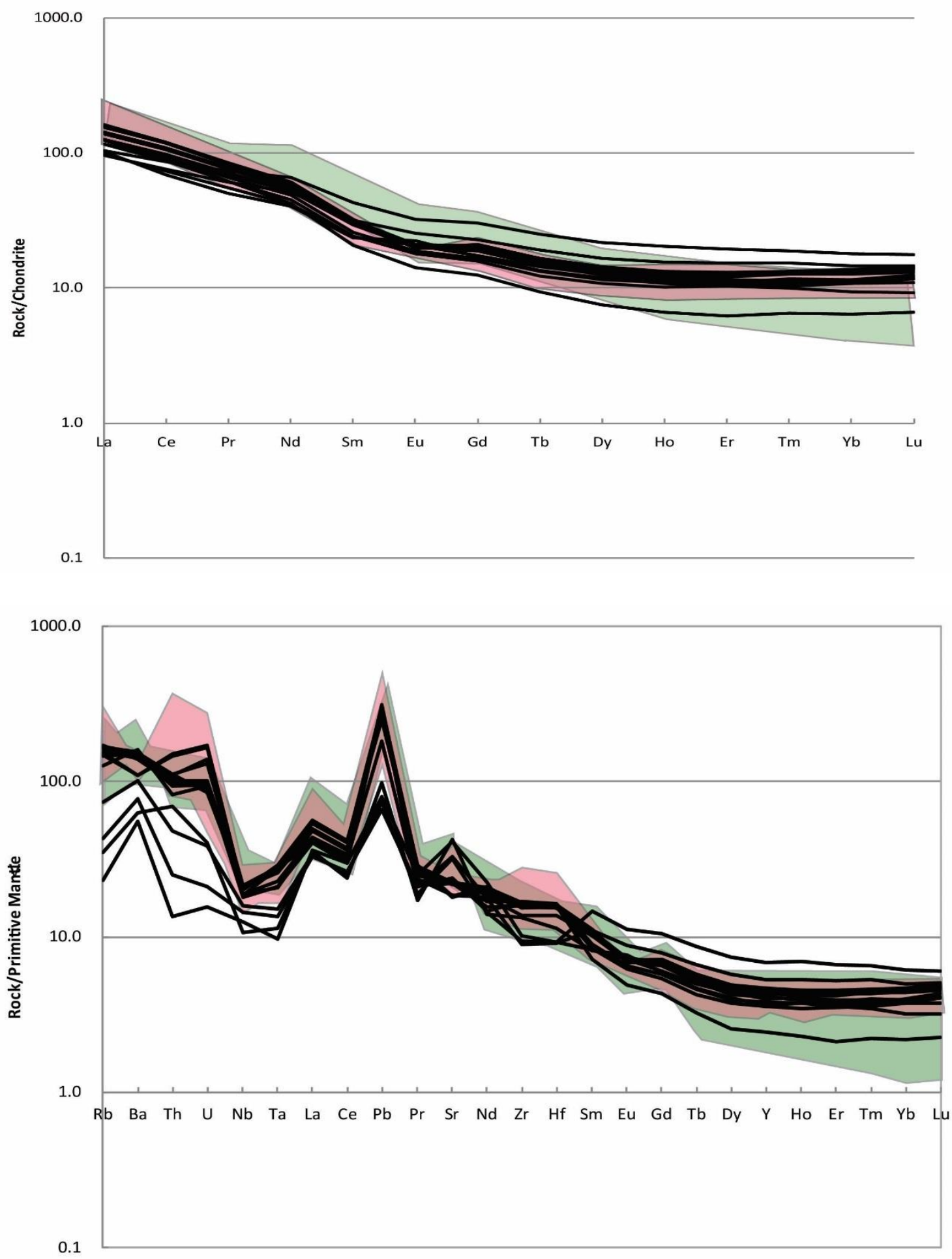

Figure 12. REE and Spider diagrams. Black lines represent Pioneer batholith samples. Shaded pink fields represent Boulder batholith samples, and shaded green areas represent Idaho batholith samples from Clarke 1990. 
fractionating assemblage) can be linked to the magmatic evolution of the Pioneer batholith from basalt to dacite, and thus may represent a liquid line of descent.

The second key factor diving magmatic evolution is plagioclase fractionation. Thin section analyses and variation diagrams first revealed evidence for fractionation. After testing for crystal fractionation, it was shown that the plagioclase dominated fractionation $(\sim 50 \%$ of the fractionation assemblage) could also be linked the magmatic evolution.

Eu troughs in the Spider and REE diagrams for the silicic Pioneer samples along with the steady decrease of Eu and $\mathrm{Sr}$ as $\mathrm{SiO}_{2}$ content increases is a characteristic of plagioclase fractionation. This is due to isomorphic substitution of $\mathrm{Eu}$ and $\mathrm{Sr}$ for $\mathrm{Ca}$ and $\mathrm{Na}$ in plagioclase resulting in troughs or peaks depending on whether plagioclase fractionation or accumulation is occurring. The Sr spike on the REE and Spider diagrams for the mafic Pioneer samples correlate with the abundance of plagioclase in the more mafic thin sections. Whereas the more silicic samples show slight Eu and Sr troughs, representing fractionation of plagioclase. This can be correlated with thin section analyses showing an abundance of plagioclase with accumulate texture in the mafic samples and much less plagioclase in the more silicic samples.

Figure 13, a diagram showing $\mathrm{Dy} / \mathrm{Yb}$ ratio decreases at $\sim 67 \mathrm{wt} \% \mathrm{SiO}_{2}$ indicating some amphibole fractionation (Keshavarzi, Esmaili, Kahkhaei, Mokhtari, \& Kordlou, 2014). This is verified in thin section due to a decrease in amphibole abundance as $\mathrm{SiO}_{2}$ content increases. Steady decreases seen in trace element variation diagrams, in $\mathrm{P}_{2} \mathrm{O}_{5}$ with increasing $\mathrm{SiO}_{2}$ content, can be attributed to apatite fractionation (Keshavarzi et al., 2014). Apatite fractionation is a minor factor in magma differentiation relative to amphibole and plagioclase fractionation. 


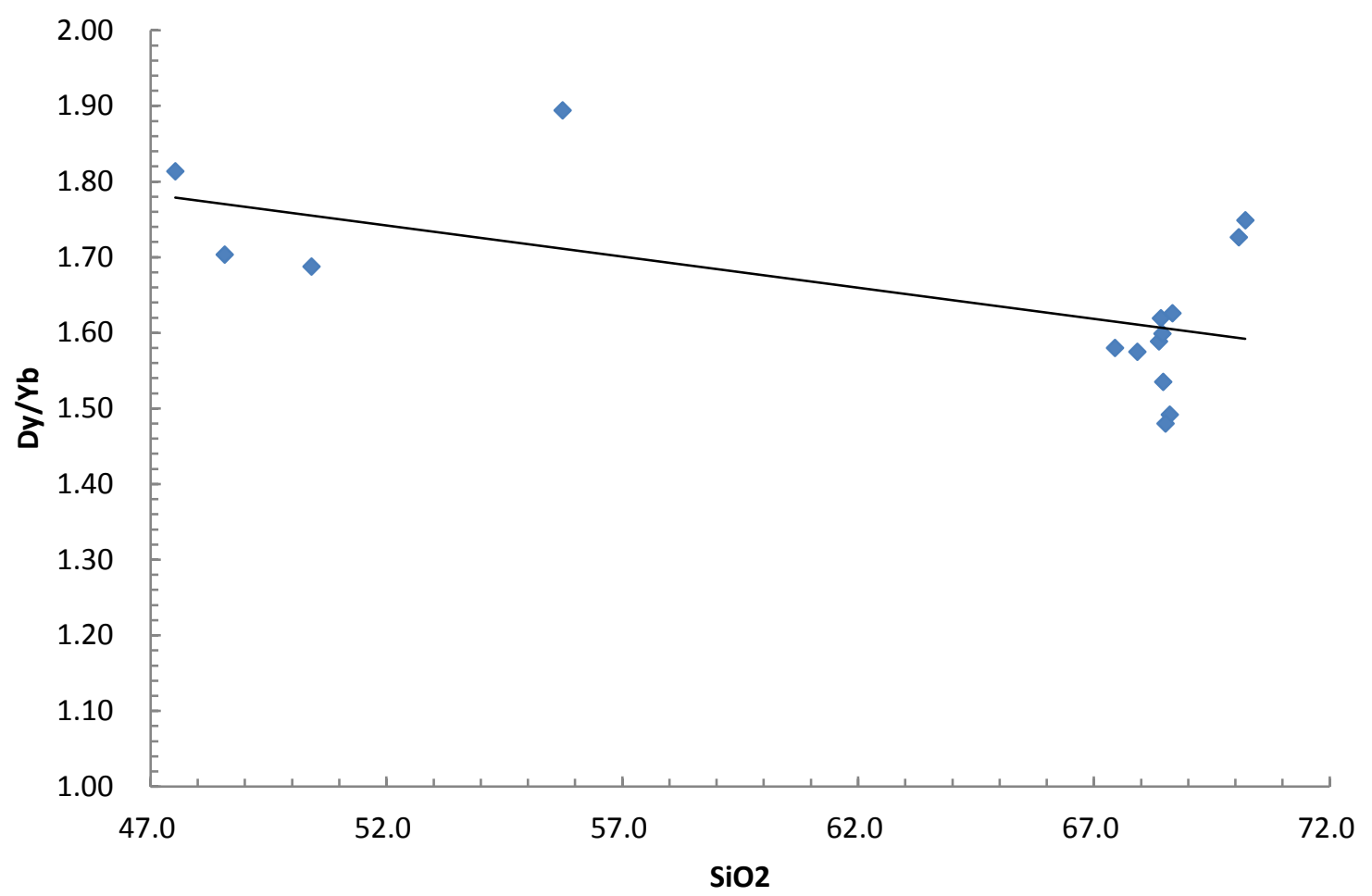

Figure $13 \mathrm{Dy} / \mathrm{YB}$ vs $\mathrm{SiO}_{2}$. The decrease of the $\mathrm{Dy} / \mathrm{Yb}$ ratio as $\mathrm{SiO}_{2}$ decreases is indicative of amphibole fractionation.

The $\mathrm{Ba} / \mathrm{Sr}$ vs. $\mathrm{SiO}_{2}$ diagram (Figure 14) shows that plagioclase and not K-feldspar was the fractionating component due to increasing $\mathrm{Ba} / \mathrm{Sr}$ ratio from the mafic to silicic components. This

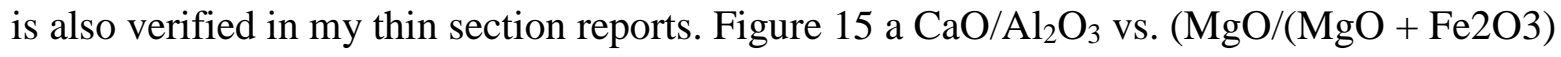
diagram shows an increase in $\mathrm{CaO} / \mathrm{Al}_{2} \mathrm{O}_{3}$ as $\mathrm{Mg \#}$ decreases (more evolved liquids); this is an indication of the removal of plagioclase which takes $\mathrm{CaO}$ and $\mathrm{Al}_{2} \mathrm{O}_{3}$ with it as it fractionates from the melt. The $\mathrm{MgO \#}$ represents the more mafic melts as $\mathrm{SiO}_{2}$ varies little in these liquids, the $\mathrm{CaO} / \mathrm{Al}_{2} \mathrm{O}_{3}$ vs. $\mathrm{SiO}_{2}$ represents the removal of plagioclase across the entire suite of PM samples. 


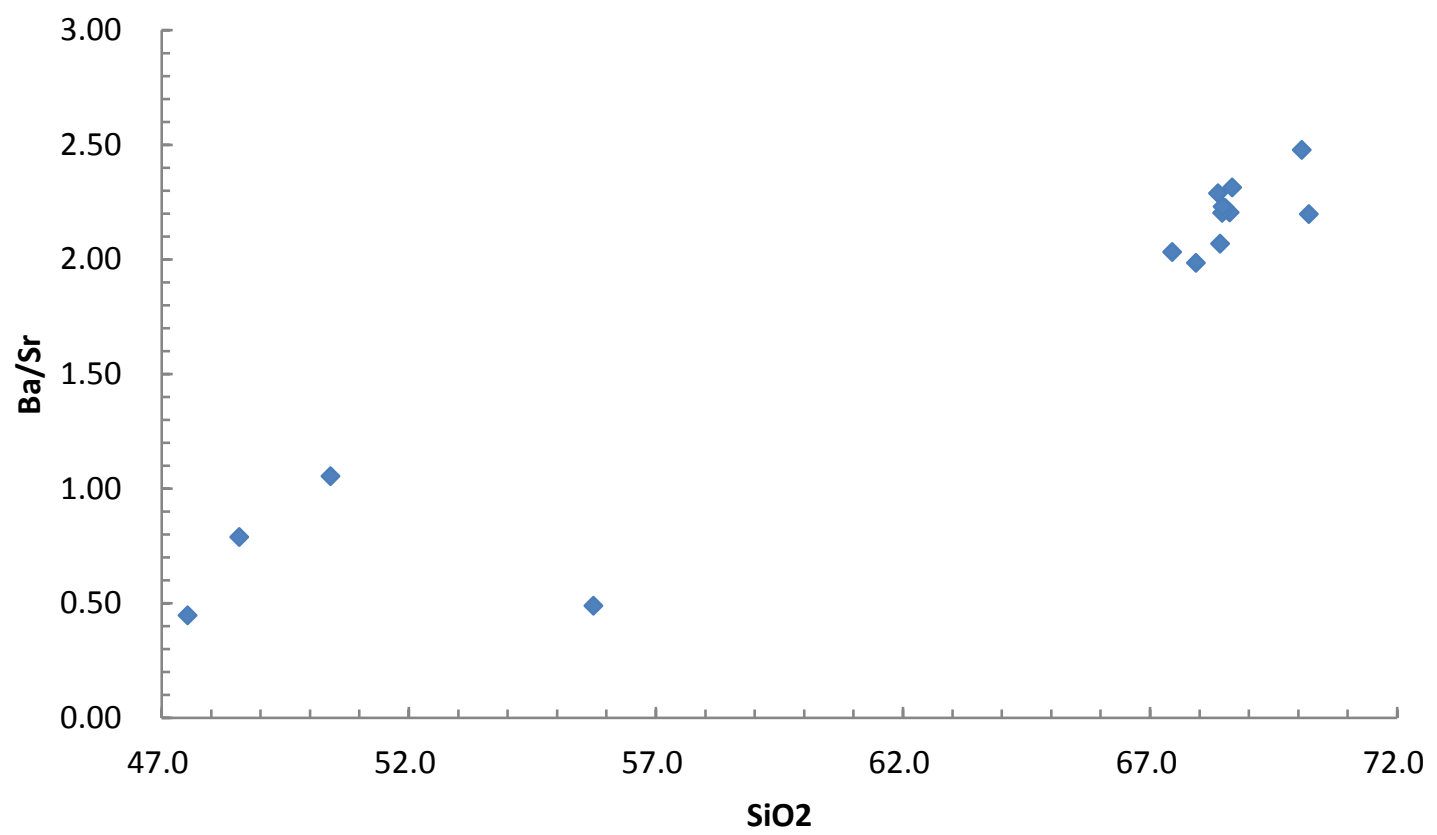

Figure $14 \mathrm{Ba} / \mathrm{Sr}$ vs $\mathrm{SiO} 2$ showing fractionation of plagioclase. $\mathrm{Ba} / \mathrm{Sr}$ ratios increase as $\mathrm{SiO}_{2}$ content increases showing plagioclase and not potassium feldspar was the dominant fractionating phase.

The geochemical data presented shows that Pioneer and Boulder batholith are comagmatic and that crystal fractionation is the main process leading to their magmatic diversity. The issue about the relative locations of the Boulder and Pioneer batholiths has not yet been explained. The involvement of the Sapphire Block leading to the emplacement of the Boulder batholith could have influenced the location of the Pioneer batholith and possibly its magma generation as well. The movement of the Sapphire block may have been responsible for the injection of the Pioneer batholith to the southeast due to depression it caused (Hyndman et al., 1975). 


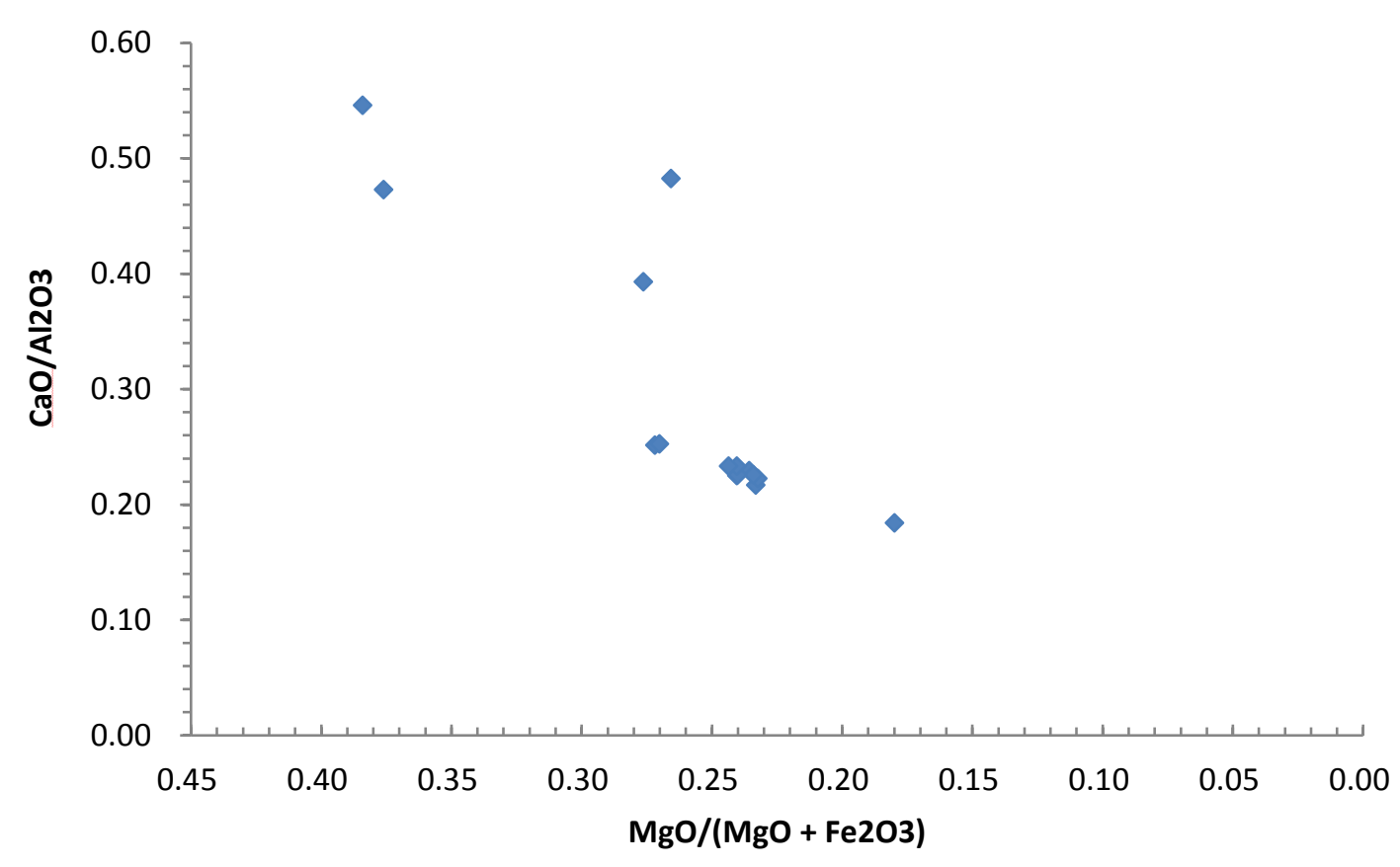

Figure $15 \mathrm{CaO} / \mathrm{Al}_{2} \mathrm{O}_{3}$ vs. $\mathrm{MgO} /\left(\mathrm{MgO}+\mathrm{Fe}_{2} \mathrm{O}_{3}\right)$. The $\mathrm{MgO \#}$ represents the more mafic melts as $\mathrm{SiO}_{2}$ varies little in these liquids, the $\mathrm{CaO} / \mathrm{Al}_{2} \mathrm{O}_{3}$ vs. $\mathrm{SiO}_{2}$ represents the removal of plagioclase across the entire suite of PM samples.

\section{CONCLUSIONS}

The Late Cretaceous Pioneer and Boulder batholiths are a product of the subduction of the Farallon plate beneath the North American plate. A subduction zone source is evident in geochemical signatures similar to subduction zone magmas in REE diagrams. Comparable $\mathrm{Sr}$ ratios for Pioneer batholith and Boulder batholith indicate a crustal component interaction with the melt.

Smooth trends on Harker variation diagrams and little variation between high silica Pioneer and Boulder batholith trace elements suggest a comagmatic relationship between the two batholiths. Overlapping emplacement dates for the Pioneer and Boulder batholiths (78-73 Ma) 
agree with a comagmatic relationship. Once a comagmatic relationship was established between the Pioneer and Boulder batholiths we tested for crystal fractionation as the key process driving magmatic evolution between the two batholiths. The Pioneer batholith samples are bimodal, comprised of silicic and mafic compositions while the Boulder batholith fills most of the intermediate composition gaps with some overlap within the silicic samples. The bimodal nature of the Pioneer batholith samples implies extensive liquid evolution which was shown by elevated $\mathrm{Hf}-\mathrm{Zr}$.

Modeling revealed that plagioclase and amphibole fractionation where the driving forces of the extensive liquid evolution seen in the Pioneer batholith. The reduction in proportions of amphibole and plagioclase, analyzed in thin section, from the mafic to silicic end-member was also evidence for crystal fractionation. Trace element data were also consistent with these two phases being the dominant fractionated material leading to the bimodal Pioneer batholith.

Amphibole fractionation may significantly influence the major element concentration in continental arc lavas and plutons. Amphibole contains significantly less $\mathrm{SiO}_{2}$ and more $\mathrm{TiO}_{2}$ than basalt, and thus during fractionation, the liquid composition would be efficiently driven to higher $\mathrm{SiO}_{2}$ and lower $\mathrm{TiO}_{2}$. Furthermore, it is within amphibole fractionation zones that water-rich magmas can become stalled during fractionation, driving the interstitial liquids to more evolved compositions. Differentiation of magmas in crustal reservoirs in conditions relevant for the for the emplacement of crustal plutons is critical for understanding the genesis of dacites and andesites and to completely produce a cortical model for the evolution of the Earth's continental crust.

The geochemical data presented shows that Pioneer and Boulder batholith are comagmatic and that crystal fractionation is the primary process leading to their magmatic 
diversity. The issue about the relative locations of the Boulder and Pioneer batholiths has not yet been explained and are outside the goals proposed for my research. Nonetheless, the involvement of the Sapphire Block leading in the emplacement of the Boulder batholith could have influenced the location of the Pioneer batholith and possibly its magma differentiation processes as well. Future models that are outside of the scope of this research must consider the evidence proposed in this document in order to produce an overarching model for the emplacement of the Pioneer and Boulder batholiths. 


\section{REFERENCES}

Algeo, T. J., \& Heckel, P. H. (2008). The Late Pennsylvanian Midcontinent Sea of North America: A review. Paleogeography, Palaeoclimatology, Palaeoecology, 268(3-4), 205221. https://doi.org/10.1016/j.palaeo.2008.03.049

Armstrong, R. L., Taubeneck, W. H., \& Hales, P. O. (1977). Rb-Sr and K-Ar geochronometry of Mesozoic granitic rocks and their $\mathrm{Sr}$ isotopic composition, Oregon, Washington, and Idaho. Geological Society of America Bulletin, 88(3), 397-411. https://doi.org/10.1130/0016-7606(1977)88<397:RAKGOM>2.0.CO;2

Atwater, T. (1970). Implications of Plate Tectonics for the Cenozoic Tectonic Evolution of Western North America. Geological Society of America Bulletin, 81(12), 3513-3536. https://doi.org/10.1130/0016-7606(1970)81[3513:IOPTFT]2.0.CO;2

Bennett, E. H. (1980). Granitic rocks of Tertiary age in the Idaho Batholith and their relation to mineralization. Economic Geology, 75(2), 278-288. https://doi.org/10.2113/gsecongeo.75.2.278

Dickinson, W. R., \& Snyder, W. S. (1978). Plate tectonics of the Laramide orogeny. Geological Society of America Memoirs, 151, 355-366. https://doi.org/10.1130/MEM151-p355

du Bray, E. A., Aleinikoff, J. N., \& Lund, K. (2012). Synthesis of petrographic, geochemical, and isotopic data for the Boulder batholith, southwest Montana (USGS Numbered Series No. 1793) (p. 46). Reston, VA: U.S. Geological Survey. Retrieved from http://pubs.er.usgs.gov/publication/pp1793

du Bray, E. A., Lund, K., Tilling, R. I., Denning, P. D., \& DeWitt, E. (2009). Geochemical Database for the Boulder Batholith and Its Satellitic Plutons, Southwest Montana. US Geological Survey. Retrieved from https://pubs.er.usgs.gov/publication/ds454 
English, J. M., \& Johnston, S. T. (2004). The Laramide Orogeny: What Were the Driving Forces? International Geology Review, 46(9), 833-838. https://doi.org/10.2747/00206814.46 .9 .833

Foster, D. A., Mueller, P. A., Heatherington, A., Gifford, J. N., \& Kalakay, T. J. (2012). Lu-Hf systematics of magmatic zircons reveal a Proterozoic crustal boundary under the Cretaceous Pioneer batholith, Montana. Lithos, 142-143, 216-225. https://doi.org/10.1016/j.lithos.2012.03.005

Foster, D. A., Mueller, P. A., Mogk, D. W., Wooden, J. L., \& Vogl, J. J. (2006). Proterozoic evolution of the western margin of the Wyoming craton: implications for the tectonic and magmatic evolution of the northern Rocky Mountains. Canadian Journal of Earth Sciences, 43(10), 1601-1619. https://doi.org/10.1139/e06-052

Foster, D. A., Schafer, C., Fanning, C. M., \& Hyndman, D. W. (2001). Relationships between crustal partial melting, plutonism, orogeny, and exhumation: Idaho-Bitterroot batholith. Tectonophysics, 342(3-4), 313-350. https://doi.org/10.1016/S0040-1951(01)00169-X

Gaschnig, R. M., Vervoort, J. D., Lewis, R. S., \& McClelland, W. C. (2010). Migrating magmatism in the northern US Cordillera: in situ U-Pb geochronology of the Idaho batholith. Contributions to Mineralogy and Petrology, 159(6), 863-883. https://doi.org/10.1007/s00410-009-0459-5

Gill, J. R., \& Cobban, W. A. (1973). Stratigraphy and geologic history of the Montana group and equivalent rocks, Montana, Wyoming, and North and South Dakota (USGS Numbered Series No. 776) (p. 36). Washington, D.C.: U.S. Government Printing Office. Retrieved from http://pubs.er.usgs.gov/publication/pp776 
Hamilton, W., \& Myers, W. B. (1974). Nature of the Boulder Batholith of Montana. Geological Society of America Bulletin, 85(3), 365-378. https://doi.org/10.1130/00167606(1974)85<365:NOTBBO>2.0.CO;2

Hammarstrom, J. M. (1982). Chemical and mineralogical variation in the Pioneer Batholith, southwest Montana (USGS Numbered Series No. 82-148). U.S. Geological Survey,. Retrieved from http://pubs.er.usgs.gov/publication/ofr82148

Hyndman, D. W. (1984). A Petrographic and Chemical Section through the Northern Idaho Batholith. The Journal of Geology, 92(1), 83-102. https://doi.org/10.1086/628836

Hyndman, D. W., Talbot, J. L., \& Chase, R. B. (1975). Boulder batholith: A result of emplacement of a block detached from the Idaho batholith infrastructure? Geology, 3(7), 401-404. https://doi.org/10.1130/0091-7613(1975)3<401:BBAROE>2.0.CO;2

James, H. L., \& Hedge, C. E. (1980). Age of the basement rocks of southwest Montana. Geological Society of America Bulletin, 91(1), 11-15. https://doi.org/10.1130/00167606(1980)91<11:AOTBRO>2.0.CO;2

Kalakay, T. J., John, B. E., \& Lageson, D. R. (2001). Fault-controlled pluton emplacement in the Sevier fold-and-thrust belt of southwest Montana, USA. Journal of Structural Geology, 23(6-7), 1151-1165. https://doi.org/10.1016/S0191-8141(00)00182-6

Keshavarzi, R., Esmaili, D., Kahkhaei, M. R., Mokhtari, M. A. A., \& Kordlou, M. (2014). Mineral Chemistry and Magmatic Differentiation Evidences in the Neshveh Intrusion (NW Saveh, Central Iran). Open Journal of Geology, 2014. https://doi.org/10.4236/ojg.2014.46020

Lund, K., Aleinikoff, J. N., Kunk, M. J., Unruh, D. M., Zeihen, G. D., Hodges, W. C., ... O’Neill, J. M. (2002). SHRIMP U-Pb and 40Ar/39Ar Age Constraints for Relating 
Plutonism and Mineralization in the Boulder Batholith Region, Montana. Economic Geology, 97(2), 241-267. https://doi.org/10.2113/gsecongeo.97.2.241

Mcdowell, F. W., \& Kulp, J. L. (1969). Potassium-Argon Dating of the Idaho Batholith. Geological Society of America Bulletin, 80(11), 2379-2382. https://doi.org/10.1130/0016-7606(1969)80[2379:PDOTIB]2.0.CO;2

Mueller, P. a., \& Shuster, R. d. (1995). Source of the Northeastern Idaho batholith: Isotopic evidence for a Paleoproterozoic terrane in... Journal of Geology, 103(1), 63.

Norman, M. D., \& Leeman, W. P. (1989). Geochemical evolution of Cenozoic-Cretaceous magmatism and its relation to tectonic setting, southwestern Idaho, U.S.A. Earth and Planetary Science Letters, 94(1), 78-96. https://doi.org/10.1016/0012-821X(89)90085-X

Paterson, S. R., \& Fowler, T. K. (1993). Re-examining pluton emplacement processes. Journal of Structural Geology, 15(2), 191-206. https://doi.org/10.1016/0191-8141(93)90095-R

Robinson, G. D., Klepper, M. R., \& Obradovich, J. D. (1968). Overlapping Plutonism, Volcanism, and Tectonism in the Boulder Batholith Region, Western Montana. Geological Society of America Memoirs, 116, 557-576. https://doi.org/10.1130/MEM116-p557

Ruppel, E. T., Wallace, C. A., Schmidt, R. G., \& Lopez, D. A. (1981). PRELIMINARY INTERPRETATION OF THE THRUST BELT IN SOUTHWEST AND WESTCENTRAL MONTANA AND EAST CENTRAL IDAHO, 139-159.

Schmidt, C. J., Smedes, H. W., \& MichaelO’Neill, J. (1990). Syncompressional Emplacement of the Boulder and Tobacco Root Batholiths (Montana-USA) by Pull-apart along Old Fault Zones. Geological Journal, 25(3-4), 305-318. https://doi.org/10.1002/gj.3350250313 
Tilling, R. I. (1974). Composition and Time Relations of Plutonic and Associated Volcanic Rocks, Boulder Batholith Region, Montana. Geological Society of America Bulletin, 85(12), 1925-1930. https://doi.org/10.1130/00167606(1974)85<1925:CATROP>2.0.CO;2

Vejmelek, L., \& Smithson, S. B. (1995). Seismic reflection profiling in the Boulder batholith, Montana. Geology, 23(9), 811-814. https://doi.org/10.1130/00917613(1995)023<0811:SRPITB>2.3.CO;2

Zen, E.-A., Marvin, R. F., \& Mehnert, H. H. (1975). Preliminary Petrographic, Chemical, and Age Data on Some Intrusive and Associated Contact Metamorphic Rocks, Pioneer Mountains, Southwestern Montana. Geological Society of America Bulletin, 86(3), 367370. https://doi.org/10.1130/0016-7606(1975)86<367:PPCAAD>2.0.CO;2 


\section{APPENDIX}

\begin{tabular}{|c|c|c|c|c|c|}
\hline Sample & $\begin{array}{l}\text { BB- } \\
\text { 14redo2 }\end{array}$ & $\begin{array}{l}\text { BB- } \\
\text { 14redo1 }\end{array}$ & BB-13 & BB-12 & BB-11 \\
\hline $\mathrm{SiO} 2$ & 66.96 & 66.91 & 62.48 & 67.70 & 64.73 \\
\hline $\mathrm{TiO} 2$ & 0.49 & 0.49 & 0.70 & 0.43 & 0.64 \\
\hline $\mathrm{Al} 2 \mathrm{O} 3$ & 15.25 & 15.21 & 16.63 & 15.45 & 15.27 \\
\hline Fe2O3 & 4.51 & 4.59 & 5.39 & 4.08 & 5.47 \\
\hline $\mathrm{MnO}$ & 0.08 & 0.08 & 0.08 & 0.08 & 0.09 \\
\hline $\mathrm{MgO}$ & 1.83 & 1.83 & 2.48 & 1.50 & 2.40 \\
\hline $\mathrm{CaO}$ & 3.74 & 3.76 & 4.77 & 3.25 & 4.16 \\
\hline $\mathrm{Na} 2 \mathrm{O}$ & 2.91 & 2.90 & 3.04 & 3.47 & 2.82 \\
\hline K2O & 4.05 & 4.06 & 4.23 & 3.86 & 4.24 \\
\hline P2O5 & 0.17 & 0.17 & 0.22 & 0.18 & 0.19 \\
\hline $\mathrm{Rb}$ & 136.86 & 140.66 & 128.43 & 149.01 & 155.60 \\
\hline $\mathrm{Zr}$ & 168.12 & 174.24 & 298.46 & 171.71 & 223.10 \\
\hline $\begin{array}{l}\text { Sr } \\
\text { V- }\end{array}$ & 478.94 & 494.52 & 527.24 & 575.91 & 443.35 \\
\hline $\begin{array}{l}\text { ICPMs } \\
\mathrm{Cr}-\end{array}$ & 82.89 & 85.86 & 108.67 & 71.13 & 109.81 \\
\hline ICPMS & 14.11 & 14.18 & 23.65 & 9.93 & 19.92 \\
\hline $\mathrm{Y}$ & 19.20 & 20.07 & 17.76 & 19.14 & 23.75 \\
\hline $\mathrm{Nb}$ & 13.24 & 13.15 & 13.65 & 15.33 & 14.62 \\
\hline $\mathrm{Ba}$ & 774.46 & 787.06 & 1098.96 & 812.22 & 763.65 \\
\hline $\mathrm{La}$ & 51.99 & 54.45 & 36.48 & 50.75 & 42.12 \\
\hline $\mathrm{Ce}$ & 93.19 & 93.47 & 67.04 & 88.98 & 81.49 \\
\hline $\mathrm{Pr}$ & 9.37 & 9.46 & 7.10 & 8.90 & 8.86 \\
\hline $\mathrm{Nd}$ & 31.38 & 32.22 & 25.84 & 29.79 & 31.60 \\
\hline $\mathrm{Sm}$ & 4.96 & 4.93 & 4.34 & 4.77 & 5.42 \\
\hline $\mathrm{Eu}$ & 1.06 & 1.09 & 1.18 & 1.01 & 1.09 \\
\hline $\mathrm{Gd}$ & 4.11 & 4.16 & 3.85 & 3.88 & 4.75 \\
\hline $\mathrm{Tb}$ & 0.57 & 0.58 & 0.52 & 0.54 & 0.67 \\
\hline Dy & 3.33 & 3.44 & 3.10 & 3.19 & 4.04 \\
\hline $\mathrm{Ho}$ & 0.67 & 0.71 & 0.63 & 0.67 & 0.83 \\
\hline $\mathrm{Er}$ & 1.97 & 2.07 & 1.82 & 1.93 & 2.45 \\
\hline Tm & 0.30 & 0.31 & 0.27 & 0.30 & 0.37 \\
\hline $\mathrm{Yb}$ & 2.08 & 2.12 & 1.84 & 2.07 & 2.51 \\
\hline Lu & 0.32 & 0.34 & 0.29 & 0.34 & 0.38 \\
\hline $\mathrm{Hf}$ & 4.78 & 5.00 & 7.68 & 5.01 & 6.29 \\
\hline Ta & 1.12 & 1.11 & 0.88 & 1.17 & 1.13 \\
\hline $\mathrm{Pb}$ & 17.72 & 17.20 & 33.40 & 12.65 & 14.99 \\
\hline Th & 18.10 & 19.87 & 14.56 & 28.80 & 21.54 \\
\hline U & 3.54 & 3.53 & 3.05 & 4.28 & 4.28 \\
\hline
\end{tabular}




\begin{tabular}{|c|c|c|c|c|c|}
\hline Sample & BB-10 & BB-09 & BB-08 & BB-07X & BB-07 \\
\hline $\mathrm{SiO} 2$ & 64.79 & 65.26 & 67.64 & 65.56 & 65.55 \\
\hline TiO2 & 0.63 & 0.60 & 0.49 & 0.49 & 0.49 \\
\hline $\mathrm{Al} 2 \mathrm{O} 3$ & 15.49 & 15.35 & 15.14 & 15.79 & 15.74 \\
\hline $\mathrm{Fe} 2 \mathrm{O} 3$ & 5.35 & 5.16 & 4.22 & 4.81 & 4.86 \\
\hline $\mathrm{MnO}$ & 0.09 & 0.09 & 0.07 & 0.08 & 0.08 \\
\hline $\mathrm{MgO}$ & 2.30 & 2.21 & 1.63 & 2.01 & 2.02 \\
\hline $\mathrm{CaO}$ & 4.14 & 3.97 & 3.24 & 4.16 & 4.18 \\
\hline $\mathrm{Na} 2 \mathrm{O}$ & 2.84 & 2.86 & 2.73 & 3.10 & 3.07 \\
\hline $\mathrm{K} 2 \mathrm{O}$ & 4.16 & 4.31 & 4.69 & 3.81 & 3.82 \\
\hline P2O5 & 0.19 & 0.18 & 0.15 & 0.18 & 0.18 \\
\hline $\mathrm{Rb}$ & 157.84 & 170.35 & 176.79 & 127.33 & 131.50 \\
\hline $\mathrm{Zr}$ & 220.81 & 234.16 & 188.94 & 171.93 & 174.17 \\
\hline $\mathrm{Sr}$ & 460.38 & 441.12 & 411.36 & 508.51 & 520.71 \\
\hline V-ICPMs & 105.86 & 100.83 & 79.08 & 89.87 & 92.55 \\
\hline Cr-ICPMS & 20.18 & 18.28 & 11.49 & 14.96 & 15.63 \\
\hline$Y$ & 22.82 & 23.65 & 21.81 & 20.16 & 20.81 \\
\hline $\mathrm{Nb}$ & 14.38 & 15.00 & 14.33 & 10.97 & 11.38 \\
\hline $\mathrm{Ba}$ & 802.64 & 746.76 & 854.74 & 775.02 & 795.24 \\
\hline La & 44.71 & 40.82 & 45.50 & 32.58 & 33.28 \\
\hline $\mathrm{Ce}$ & 83.74 & 80.58 & 86.83 & 62.32 & 63.00 \\
\hline $\mathrm{Pr}$ & 8.91 & 8.73 & 9.07 & 6.86 & 6.97 \\
\hline $\mathrm{Nd}$ & 31.48 & 31.39 & 31.42 & 25.17 & 25.81 \\
\hline Sm & 5.38 & 5.39 & 5.18 & 4.50 & 4.74 \\
\hline $\mathrm{Eu}$ & 1.13 & 1.08 & 1.00 & 1.07 & 1.07 \\
\hline $\mathrm{Gd}$ & 4.63 & 4.70 & 4.40 & 4.04 & 4.15 \\
\hline $\mathrm{Tb}$ & 0.65 & 0.67 & 0.61 & 0.56 & 0.59 \\
\hline Dy & 3.84 & 4.00 & 3.64 & 3.46 & 3.59 \\
\hline Ho & 0.80 & 0.82 & 0.76 & 0.71 & 0.73 \\
\hline $\mathrm{Er}$ & 2.31 & 2.40 & 2.27 & 2.06 & 2.12 \\
\hline $\mathrm{Tm}$ & 0.35 & 0.36 & 0.35 & 0.32 & 0.32 \\
\hline $\mathrm{Yb}$ & 2.35 & 2.41 & 2.31 & 2.08 & 2.16 \\
\hline Lu & 0.37 & 0.38 & 0.36 & 0.33 & 0.35 \\
\hline $\mathrm{Hf}$ & 6.07 & 6.50 & 5.57 & 4.91 & 5.04 \\
\hline $\mathrm{Ta}$ & 1.08 & 1.09 & 1.07 & 0.80 & 0.83 \\
\hline $\mathrm{Pb}$ & 17.28 & 18.29 & 15.70 & 15.46 & 15.74 \\
\hline Th & 22.51 & 24.46 & 30.86 & 17.65 & 17.04 \\
\hline U & 4.43 & 4.52 & 5.69 & 3.71 & 3.77 \\
\hline
\end{tabular}




\begin{tabular}{|c|c|c|c|c|c|}
\hline Sample & BB-06 & BB-05 & BB-04X & BB-04 & BB-03 \\
\hline $\mathrm{SiO} 2$ & 58.55 & 67.01 & 62.34 & 62.36 & 61.49 \\
\hline TiO2 & 0.79 & 0.36 & 0.58 & 0.58 & 0.55 \\
\hline $\mathrm{Al} 2 \mathrm{O} 3$ & 17.10 & 16.52 & 16.66 & 16.60 & 16.07 \\
\hline $\mathrm{Fe} 2 \mathrm{O} 3$ & 7.44 & 3.72 & 6.11 & 6.11 & 6.61 \\
\hline $\mathrm{MnO}$ & 0.14 & 0.09 & 0.13 & 0.13 & 0.13 \\
\hline $\mathrm{MgO}$ & 3.31 & 1.26 & 2.22 & 2.26 & 2.92 \\
\hline $\mathrm{CaO}$ & 5.76 & 4.20 & 5.27 & 5.30 & 5.69 \\
\hline $\mathrm{Na} 2 \mathrm{O}$ & 3.88 & 3.96 & 3.68 & 3.67 & 3.45 \\
\hline $\mathrm{K} 2 \mathrm{O}$ & 2.75 & 2.70 & 2.78 & 2.76 & 2.84 \\
\hline P2O5 & 0.28 & 0.17 & 0.23 & 0.23 & 0.26 \\
\hline $\mathrm{Rb}$ & 159.29 & 69.35 & 67.32 & 65.94 & 67.11 \\
\hline $\mathrm{Zr}$ & 181.37 & 134.47 & 184.48 & 188.68 & 158.19 \\
\hline $\mathrm{Sr}$ & 509.44 & 810.66 & 795.72 & 799.88 & 767.88 \\
\hline V-ICPMs & 145.39 & 48.86 & 99.60 & 100.33 & 120.04 \\
\hline Cr-ICPMS & 17.61 & 11.44 & 10.31 & 9.74 & 26.48 \\
\hline$Y$ & 21.92 & 14.37 & 22.31 & 22.24 & 20.97 \\
\hline $\mathrm{Nb}$ & 16.76 & 12.98 & 13.15 & 13.43 & 11.29 \\
\hline $\mathrm{Ba}$ & 451.03 & 1137.53 & 1115.15 & 1149.08 & 901.21 \\
\hline $\mathrm{La}$ & 38.23 & 29.04 & 30.28 & 30.19 & 29.17 \\
\hline $\mathrm{Ce}$ & 77.14 & 56.03 & 59.31 & 59.71 & 56.87 \\
\hline $\mathrm{Pr}$ & 8.47 & 5.67 & 6.81 & 6.75 & 6.46 \\
\hline $\mathrm{Nd}$ & 30.12 & 20.11 & 25.66 & 25.70 & 24.80 \\
\hline $\mathrm{Sm}$ & 5.22 & 3.39 & 4.87 & 4.91 & 4.64 \\
\hline $\mathrm{Eu}$ & 1.11 & 0.95 & 1.33 & 1.31 & 1.20 \\
\hline $\mathrm{Gd}$ & 4.54 & 2.90 & 4.42 & 4.41 & 4.25 \\
\hline $\mathrm{Tb}$ & 0.62 & 0.40 & 0.63 & 0.62 & 0.60 \\
\hline Dy & 3.69 & 2.40 & 3.76 & 3.76 & 3.60 \\
\hline $\mathrm{Ho}$ & 0.78 & 0.49 & 0.79 & 0.80 & 0.75 \\
\hline $\mathrm{Er}$ & 2.26 & 1.47 & 2.31 & 2.29 & 2.15 \\
\hline $\mathrm{Tm}$ & 0.35 & 0.23 & 0.35 & 0.35 & 0.33 \\
\hline $\mathrm{Yb}$ & 2.38 & 1.58 & 2.34 & 2.38 & 2.18 \\
\hline Lu & 0.39 & 0.26 & 0.36 & 0.38 & 0.35 \\
\hline $\mathrm{Hf}$ & 5.18 & 3.63 & 4.78 & 4.87 & 4.36 \\
\hline $\mathrm{Ta}$ & 1.26 & 0.71 & 0.87 & 0.83 & 0.71 \\
\hline $\mathrm{Pb}$ & 12.46 & 10.68 & 12.62 & 12.22 & 13.95 \\
\hline Th & 12.24 & 7.26 & 8.57 & 8.59 & 7.21 \\
\hline U & 4.77 & 1.43 & 1.26 & 1.21 & 1.23 \\
\hline
\end{tabular}




\begin{tabular}{|c|c|c|c|}
\hline Sample & BB-02X & BB-02 & BB-01 \\
\hline $\mathrm{SiO} 2$ & 65.26 & 65.25 & 64.84 \\
\hline TiO2 & 0.54 & 0.54 & 0.57 \\
\hline $\mathrm{Al} 2 \mathrm{O} 3$ & 15.43 & 15.45 & 15.41 \\
\hline $\mathrm{Fe} 2 \mathrm{O} 3$ & 5.00 & 4.97 & 4.97 \\
\hline $\mathrm{MnO}$ & 0.10 & 0.10 & 0.09 \\
\hline $\mathrm{MgO}$ & 2.19 & 2.18 & 2.26 \\
\hline $\mathrm{CaO}$ & 4.02 & 4.02 & 3.87 \\
\hline $\mathrm{Na2O}$ & 3.37 & 3.39 & 3.39 \\
\hline K2O & 3.91 & 3.91 & 4.43 \\
\hline P2O5 & 0.18 & 0.18 & 0.17 \\
\hline $\mathrm{Rb}$ & 102.02 & 100.69 & 126.59 \\
\hline $\mathrm{Zr}$ & 238.62 & 236.71 & 251.88 \\
\hline $\mathrm{Sr}$ & 583.36 & 578.56 & 545.30 \\
\hline V-ICPMs & 91.12 & 89.54 & 97.60 \\
\hline Cr-ICPMS & 33.16 & 31.93 & 48.79 \\
\hline Y & 19.52 & 19.37 & 19.54 \\
\hline $\mathrm{Nb}$ & 16.39 & 16.37 & 19.57 \\
\hline $\mathrm{Ba}$ & 1013.08 & 1000.84 & 978.07 \\
\hline $\mathrm{La}$ & 30.58 & 29.90 & 34.52 \\
\hline $\mathrm{Ce}$ & 59.16 & 57.94 & 65.98 \\
\hline $\mathrm{Pr}$ & 6.55 & 6.41 & 7.14 \\
\hline $\mathrm{Nd}$ & 24.25 & 23.87 & 25.86 \\
\hline $\mathrm{Sm}$ & 4.43 & 4.33 & 4.59 \\
\hline Eu & 1.07 & 1.07 & 1.04 \\
\hline Gd & 3.97 & 3.84 & 4.00 \\
\hline $\mathrm{Tb}$ & 0.55 & 0.54 & 0.56 \\
\hline Dy & 3.31 & 3.25 & 3.32 \\
\hline $\mathrm{Ho}$ & 0.69 & 0.69 & 0.68 \\
\hline $\mathrm{Er}$ & 2.05 & 2.00 & 1.99 \\
\hline $\mathrm{Tm}$ & 0.32 & 0.31 & 0.31 \\
\hline $\mathrm{Yb}$ & 2.16 & 2.11 & 2.11 \\
\hline Lu & 0.34 & 0.34 & 0.33 \\
\hline $\mathrm{Hf}$ & 6.29 & 6.29 & 6.70 \\
\hline $\mathrm{Ta}$ & 0.96 & 0.97 & 1.16 \\
\hline $\mathrm{Pb}$ & 18.33 & 18.06 & 18.25 \\
\hline Th & 10.86 & 10.86 & 12.96 \\
\hline U & 0.96 & 0.98 & 1.25 \\
\hline
\end{tabular}




\begin{tabular}{|c|c|c|c|c|c|c|c|}
\hline Sample & PM011 & $\begin{array}{l}\mathrm{PM}-010 \\
\text { redo }\end{array}$ & PM010 & PM-009 & PM-008 & $\begin{array}{l}\text { PM-007 } \\
\text { repeat }\end{array}$ & PM-007 \\
\hline $\mathrm{SiO} 2$ & 70.07 & 67.92 & 67.45 & 70.21 & 68.42 & 68.66 & 68.38 \\
\hline $\mathrm{TiO} 2$ & 0.36 & 0.45 & 0.46 & 0.28 & 0.37 & 0.37 & 0.39 \\
\hline $\mathrm{Al} 2 \mathrm{O} 3$ & 15.09 & 15.56 & 15.73 & 16.36 & 16.17 & 15.77 & 15.82 \\
\hline Fe2O3 & 3.45 & 4.23 & 4.33 & 2.30 & 3.38 & 3.74 & 3.80 \\
\hline $\mathrm{MnO}$ & 0.07 & 0.08 & 0.09 & 0.04 & 0.08 & 0.09 & 0.09 \\
\hline $\mathrm{MgO}$ & 1.05 & 1.58 & 1.60 & 0.50 & 1.04 & 1.13 & 1.16 \\
\hline $\mathrm{CaO}$ & 3.27 & 3.91 & 3.98 & 3.02 & 3.71 & 3.51 & 3.57 \\
\hline $\mathrm{Na} 2 \mathrm{O}$ & 3.30 & 3.38 & 3.42 & 4.37 & 3.62 & 3.39 & 3.43 \\
\hline $\mathrm{K} 2 \mathrm{O}$ & 3.21 & 2.74 & 2.79 & 2.82 & 3.05 & 3.18 & 3.21 \\
\hline P2O5 & 0.12 & 0.14 & 0.14 & 0.09 & 0.14 & 0.14 & 0.15 \\
\hline $\mathrm{Rb}$ & 109.20 & 93.36 & 97.63 & 80.00 & 98.16 & 103.06 & 106.74 \\
\hline $\mathrm{Zr}$ & 153.56 & 175.67 & 170.56 & 189.45 & 175.35 & 178.72 & 176.90 \\
\hline $\begin{array}{l}\text { Sr } \\
\text { V- }\end{array}$ & 389.71 & 387.85 & 379.06 & 505.96 & 477.65 & 458.15 & 468.06 \\
\hline $\begin{array}{l}\text { ICPMs } \\
\text { Cr- }\end{array}$ & 43.57 & 66.33 & 68.30 & 20.34 & 40.41 & 44.76 & 46.36 \\
\hline ICPMS & 6.44 & 8.65 & 9.35 & 4.90 & 3.24 & 4.93 & 4.58 \\
\hline$Y$ & 18.70 & 21.24 & 20.81 & 11.10 & 18.87 & 20.66 & 20.67 \\
\hline $\mathrm{Nb}$ & 13.33 & 14.39 & 14.40 & 13.41 & 15.32 & 14.87 & 15.37 \\
\hline $\mathrm{Ba}$ & 965.49 & 770.17 & 770.34 & 1112.39 & 987.89 & 1059.95 & 1071.12 \\
\hline $\mathrm{La}$ & 27.75 & 38.57 & 37.49 & 29.49 & 30.06 & 33.38 & 32.79 \\
\hline $\mathrm{Ce}$ & 56.09 & 73.73 & 73.05 & 56.18 & 60.17 & 65.45 & 64.32 \\
\hline $\operatorname{Pr}$ & 6.54 & 8.00 & 7.80 & 5.82 & 6.81 & 7.27 & 7.16 \\
\hline $\mathrm{Nd}$ & 24.31 & 28.39 & 28.21 & 19.66 & 25.15 & 26.58 & 25.92 \\
\hline Sm & 4.50 & 4.97 & 4.88 & 3.18 & 4.48 & 4.74 & 4.75 \\
\hline $\mathrm{Eu}$ & 1.20 & 1.14 & 1.14 & 0.82 & 1.16 & 1.19 & 1.15 \\
\hline $\mathrm{Gd}$ & 4.02 & 4.29 & 4.16 & 2.55 & 3.88 & 4.25 & 4.09 \\
\hline $\mathrm{Tb}$ & 0.58 & 0.62 & 0.60 & 0.35 & 0.55 & 0.62 & 0.58 \\
\hline Dy & 3.19 & 3.64 & 3.54 & 1.89 & 3.15 & 3.63 & 3.48 \\
\hline $\mathrm{Ho}$ & 0.64 & 0.75 & 0.73 & 0.37 & 0.64 & 0.74 & 0.72 \\
\hline $\mathrm{Er}$ & 1.75 & 2.17 & 2.13 & 1.02 & 1.82 & 2.15 & 2.08 \\
\hline $\mathrm{Tm}$ & 0.28 & 0.34 & 0.33 & 0.16 & 0.30 & 0.33 & 0.32 \\
\hline $\mathrm{Yb}$ & 1.85 & 2.31 & 2.24 & 1.08 & 1.94 & 2.23 & 2.19 \\
\hline Lu & 0.28 & 0.37 & 0.36 & 0.17 & 0.31 & 0.35 & 0.35 \\
\hline $\mathrm{Hf}$ & 4.22 & 4.99 & 4.79 & 4.91 & 4.72 & 4.87 & 4.70 \\
\hline $\mathrm{Ta}$ & 1.13 & 1.18 & 1.15 & 0.84 & 1.15 & 1.08 & 1.05 \\
\hline $\mathrm{Pb}$ & 20.81 & 18.07 & 17.79 & 13.01 & 22.13 & 21.04 & 20.79 \\
\hline Th & 8.34 & 12.73 & 12.46 & 6.99 & 8.63 & 9.48 & 9.29 \\
\hline$U$ & 2.02 & 3.56 & 3.45 & 1.96 & 2.14 & 2.74 & 2.92 \\
\hline
\end{tabular}


PM- PM- PM-

Sample 006redo2 006redo1 005repeat PM-005 PM-004 PM-003 PM-002

\begin{tabular}{|c|c|c|c|c|c|c|c|}
\hline $\mathrm{SiO} 2$ & 68.61 & 68.52 & 68.46 & 68.47 & 48.57 & 50.41 & 47.52 \\
\hline TiO2 & 0.37 & 0.37 & 0.38 & 0.38 & 1.19 & 1.05 & 1.21 \\
\hline $\mathrm{Al} 2 \mathrm{O} 3$ & 15.85 & 15.87 & 15.89 & 15.89 & 18.19 & 18.68 & 20.91 \\
\hline $\mathrm{Fe} 2 \mathrm{O} 3$ & 3.63 & 3.67 & 3.64 & 3.61 & 10.82 & 10.16 & 11.42 \\
\hline $\mathrm{MnO}$ & 0.08 & 0.08 & 0.09 & 0.08 & 0.18 & 0.16 & 0.17 \\
\hline $\mathrm{MgO}$ & 1.15 & 1.16 & 1.15 & 1.16 & 6.75 & 6.12 & 4.13 \\
\hline $\mathrm{CaO}$ & 3.57 & 3.58 & 3.71 & 3.71 & 9.94 & 8.84 & 10.09 \\
\hline $\mathrm{Na} 2 \mathrm{O}$ & 3.45 & 3.43 & 3.44 & 3.46 & 2.80 & 2.52 & 3.41 \\
\hline $\mathrm{K} 2 \mathrm{O}$ & 3.15 & 3.17 & 3.10 & 3.09 & 1.27 & 1.83 & 0.78 \\
\hline P2O5 & 0.14 & 0.14 & 0.15 & 0.15 & 0.29 & 0.22 & 0.35 \\
\hline $\mathrm{Rb}$ & 103.18 & 105.00 & 92.62 & 94.53 & 27.35 & 46.91 & 14.69 \\
\hline $\mathrm{Zr}$ & 177.42 & 187.73 & 185.95 & 182.17 & 100.65 & 105.88 & 113.97 \\
\hline $\mathrm{Sr}$ & 466.79 & 486.29 & 475.72 & 467.78 & 689.28 & 672.03 & 866.69 \\
\hline $\begin{array}{l}\text { V-ICPMs } \\
\text { Cr- }\end{array}$ & 43.32 & 44.16 & 43.09 & 42.97 & 243.60 & 209.42 & 202.80 \\
\hline ICPMS & 6.91 & 6.81 & 4.31 & 4.35 & 187.58 & 40.36 & 9.50 \\
\hline $\mathrm{Y}$ & 16.29 & 17.19 & 21.30 & 19.76 & 24.01 & 18.22 & 30.95 \\
\hline $\mathrm{Nb}$ & 12.81 & 13.38 & 15.00 & 14.88 & 10.33 & 11.27 & 8.97 \\
\hline $\mathrm{Ba}$ & 1029.56 & 1081.75 & 1048.13 & 1043.47 & 543.61 & 708.61 & 388.33 \\
\hline $\mathrm{La}$ & 27.76 & 29.97 & 36.77 & 34.11 & 22.71 & 23.28 & 24.74 \\
\hline $\mathrm{Ce}$ & 53.38 & 57.09 & 71.88 & 66.60 & 46.48 & 45.20 & 52.70 \\
\hline $\mathrm{Pr}$ & 5.87 & 6.29 & 7.80 & 7.40 & 5.81 & 5.22 & 6.97 \\
\hline $\mathrm{Nd}$ & 21.15 & 22.77 & 28.19 & 27.04 & 23.91 & 19.50 & 30.52 \\
\hline Sm & 3.72 & 3.97 & 4.84 & 4.56 & 4.86 & 3.67 & 6.52 \\
\hline $\mathrm{Eu}$ & 1.04 & 1.09 & 1.22 & 1.20 & 1.47 & 1.20 & 1.88 \\
\hline $\mathrm{Gd}$ & 3.23 & 3.43 & 4.16 & 4.00 & 4.69 & 3.58 & 6.24 \\
\hline $\mathrm{Tb}$ & 0.46 & 0.49 & 0.61 & 0.57 & 0.72 & 0.54 & 0.93 \\
\hline Dy & 2.74 & 2.91 & 3.50 & 3.32 & 4.20 & 3.22 & 5.48 \\
\hline Ho & 0.57 & 0.62 & 0.72 & 0.69 & 0.88 & 0.67 & 1.15 \\
\hline $\mathrm{Er}$ & 1.69 & 1.77 & 2.07 & 2.00 & 2.52 & 1.90 & 3.20 \\
\hline $\mathrm{Tm}$ & 0.26 & 0.27 & 0.34 & 0.32 & 0.39 & 0.29 & 0.48 \\
\hline $\mathrm{Yb}$ & 1.84 & 1.97 & 2.19 & 2.16 & 2.47 & 1.91 & 3.02 \\
\hline $\mathrm{Lu}$ & 0.30 & 0.32 & 0.36 & 0.33 & 0.37 & 0.30 & 0.45 \\
\hline $\mathrm{Hf}$ & 4.82 & 5.07 & 4.97 & 4.92 & 2.80 & 2.86 & 2.86 \\
\hline $\mathrm{Ta}$ & 0.86 & 0.93 & 1.10 & 1.06 & 0.56 & 0.62 & 0.40 \\
\hline $\mathrm{Pb}$ & 20.71 & 21.10 & 21.58 & 21.48 & 4.65 & 5.19 & 5.68 \\
\hline Th & 7.88 & 8.18 & 9.44 & 8.98 & 2.12 & 4.06 & 1.15 \\
\hline U & 2.00 & 2.08 & 1.80 & 1.86 & 0.45 & 0.81 & 0.33 \\
\hline
\end{tabular}




$\begin{array}{lr}\text { Sample } & \text { PM-001 } \\ \text { SiO2 } & 55.73 \\ \text { TiO2 } & 0.69 \\ \mathrm{Al} 2 \mathrm{O} 3 & 21.11 \\ \mathrm{Fe} 2 \mathrm{O} 3 & 6.44 \\ \mathrm{MnO} & 0.09 \\ \mathrm{MgO} & 2.46 \\ \mathrm{CaO} & 8.30 \\ \mathrm{Na} 2 \mathrm{O} & 3.96 \\ \mathrm{~K} 2 \mathrm{O} & 0.95 \\ \mathrm{P} 2 \mathrm{O} 5 & 0.26 \\ \mathrm{Rb} & 22.16 \\ \mathrm{Zr} & 148.82 \\ \mathrm{Sr} & 892.69 \\ \mathrm{~V}- & \\ \mathrm{ICPMs} & 106.67 \\ \mathrm{Cr}- & \\ \mathrm{ICPMS} & 19.02 \\ \mathrm{Y} & 16.46 \\ \mathrm{Nb} & 7.64 \\ \mathrm{Ba} & 437.34 \\ \mathrm{La} & 24.39 \\ \mathrm{Ce} & 42.36 \\ \mathrm{Pr} & 4.77 \\ \mathrm{Nd} & 18.81 \\ \mathrm{Sm} & 3.61 \\ \mathrm{Eu} & 1.29 \\ \mathrm{Gd} & 3.54 \\ \mathrm{~Tb} & 0.51 \\ \mathrm{Dy} & 3.00 \\ \mathrm{Ho} & 0.61 \\ \mathrm{Er} & 1.71 \\ \mathrm{Tm} & 0.25 \\ \mathrm{Yb} & 1.59 \\ \mathrm{Lu} & 0.23 \\ \mathrm{Hf} & 3.53 \\ \mathrm{Ta} & 0.47 \\ \mathrm{~Pb} & 6.94 \\ \mathrm{Th} & 5.86 \\ \mathrm{U} & 0.84\end{array}$

